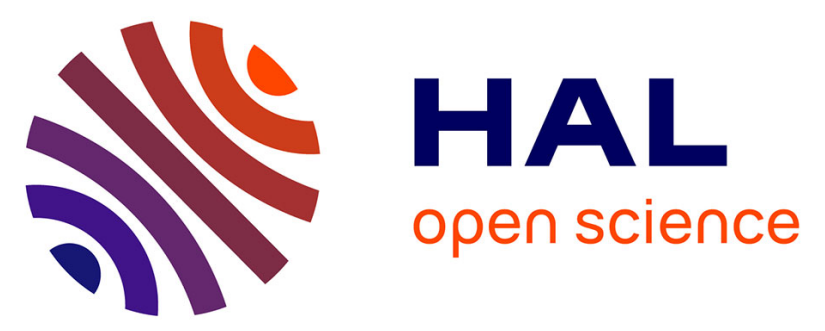

\title{
Geochemical signature of paleofluids in microstructures from Main Fault in the Opalinus Clay of the Mont Terri rock laboratory, Switzerland
}

\author{
Norbert Clauer, I. Techer, Christophe Nussbaum, Ben Laurich
}

\section{- To cite this version:}

Norbert Clauer, I. Techer, Christophe Nussbaum, Ben Laurich. Geochemical signature of paleofluids in microstructures from Main Fault in the Opalinus Clay of the Mont Terri rock laboratory, Switzerland. Swiss Journal of Geosciences, 2017, 110 (1), pp.105128. 10.1007/s00015-016-0253-0 . hal-01544318

\author{
HAL Id: hal-01544318 \\ https://hal.science/hal-01544318
}

Submitted on 11 Jul 2017

HAL is a multi-disciplinary open access archive for the deposit and dissemination of scientific research documents, whether they are published or not. The documents may come from teaching and research institutions in France or abroad, or from public or private research centers.
L'archive ouverte pluridisciplinaire HAL, est destinée au dépôt et à la diffusion de documents scientifiques de niveau recherche, publiés ou non, émanant des établissements d'enseignement et de recherche français ou étrangers, des laboratoires publics ou privés.

\section{(ㅇ)(1) $\$$}

Distributed under a Creative Commons Attribution - NonCommercial - NoDerivatives| 4.0 


\title{
Geochemical signature of paleofluids in microstructures from Main Fault in the Opalinus Clay of the Mont Terri rock laboratory, Switzerland
}

\author{
Norbert Clauer $^{1}$ - Isabelle Techer ${ }^{2}$ - Christophe Nussbaum ${ }^{3}$ - Ben Laurich ${ }^{4,5}$
}

\begin{abstract}
The present study reports on elemental and $\mathbf{S r}$ isotopic analyses of calcte and associated celestite infillings of varions nicrolectonic features collected nostly in the Main Fault of the Opalinus Clay from Mont Terri rock taboratory. Based on a detaited microstructural description of veins, slickensides, scaly clay aggregates and gouges, the geochemical signatures of the infllings were compared to those of the leachates from undeformed Opalinus Clay, and to the calcite from veins crosscutting Hauptrogenstein, Passwang and Staffelegg Formations above and below the Opalinus Clay. Vein calcite and celestite from Main Fault yield identical ${ }^{87} \mathrm{Sr}{ }^{86} \mathrm{Sr}$ ratios that are also close to those recorded in the Opalinus Clay matrix inside the Main Fault, but different from those of the diffuse Opalinus Clay calcite outside the fault. These varied ${ }^{87} \mathrm{Sr} /{ }^{86} \mathrm{Sr}$ ratios of the diffuse calcite evidence a
\end{abstract}

Editorial handling; P. Bossart and A. G. Milnes.

This is paper \#5 in the Mont Terri Special Issue of the Swiss Journal of Geosciences (see Bossart et al. 2017, Table 3 and Fig. 7)

[X] Norbert Clater nchauer@unistra.fr

1 Laboraloire d'Hydrologic el de Gcoochimie de Strasbourg (CNRS-UdS). I rue Blessig, 67084 Strasbourg, France

2 Equipe Associée 7352 CHROME, Université de NAtmes, nue dı Dr. Gcorges Salan, 30021 Nâmes, France

3 Swiss Geological Survey, Federal Office of Topograptiy Swisstopo, Seftigensirasse 264. 3084 Wabern, Switzerland

" Strictural Geology, Tectonics and Geomechenics, RW'rH Aachen University, Lochncrstrasse 4-20, 52056 Aachen, Germany

5 Federal hnsitute for Gcosciences and Natural Resources BGR, Stilleweg 2. 30655 Hamover, Gemmu lack of interaction among the associated connate waters and the flowing fluids characterized by a homogeneous $\mathrm{Sr}$ signature. The ${ }^{87} \mathrm{Sr} /{ }^{86} \mathrm{St}$ homogeneity at $0.70774 \pm$ $0.0000 t(2 \sigma)$ for the infillings of most microstructures in the Majn Fault, as well as of veins from nearby limestone layer and sediments around the Opalinus Clay, claims for an "infinite" homogeneous marine supply, whereas the gouge infillings apparently interacted with a fluid chemically more complex. According to the known regional paleogeographic evolution, two seawater supplies were inferred and documented in the Delémont Basin: either during the Priabonian (38-34 Ma ago) from western Bresse graben, and/or during the Rupelian (34-28 Ma ago) from northern Rhtne Graben. The Rupelian seawater that yiclds a mean ${ }^{87} \mathrm{Sr} /{ }^{86} \mathrm{Sr}$ signature significantly higher then those of the microstructural infillings seems not to be the appropriate source. Alternatively, Priabonian seawater yields a mean ${ }^{87} \mathrm{Sr} /{ }^{86} \mathrm{Sr}$ ratio precisely matching that of the leachates from diffuse calcite of the Opalinus Clay inside the Main Fuult, as well as that of its microstructures and the same features of the sediments above and below. To envision a Priabonian seawater supply, there is a need for its storage without a significant evolution in its $\mathrm{S}_{\mathrm{r}}$ isotopic composition until the final deformation of the area. The paleo-hydrogeological context calls for a possible infiltration of the seawater into a limestone karst located above the Opalinus Clay that could have acted as the storage reservoir. The karstic nature of this reservoir also explains why the ${ }^{87} \mathrm{Sr} /{ }^{86} \mathrm{Sr}$ of the fluids was not modified significantly unti] expulsion. An alternative storage could have been provided by the regional faulting system that developed during the contemporary regional rifting of the Rhine Graben. The fluid expulsion started along these extensional faults during the further Upper Eocene-Lower Oligocene rifting phase. Later, the thin- 
skinned deformation of the Jura Belt affected the Mont Terri region in the form of the Main Fault, probably between approximately 9 and $4 \mathrm{Ma}$ on the basis of preliminary $\mathrm{K}-\mathrm{Ar}$ ages of nanometer-sized authigenic illite crystals recovered from gouge samples.

Keywords Microtectonic features - Calcite infillings . Elemental and ${ }^{87} \mathrm{Sr} /{ }^{86} \mathrm{Sr}$ geochemistry $\cdot$ Regional geological evolution - Fluid diffusion vs. fluid flow - Past seawater vs. present-day free water

\section{Introduction}

Petrophysical characteristics of argillaceous sediments are critically important for a reliable evaluation of their abilities to safely confine buried wastes, especially those of the nuclear industry. Low porosity/permeability properties of such potential repositories represent parameters of prime importance as they depend on the intensity of their compaction/cementation (Worden and Morad 2003; Burley and Worden 2003), but also on their structural evolution that can develop post-deposition features able to favor fluid migrations, interactions with the rock materials (Urai and Wong 1994; Mitra and Ismat 2001; Warr and Cox 2001; Milliken and Reed 2010; Buatier et al. 2012), and exportation of released radionuclides. In this context, the Opalinus Clay of the Mont Terri rock laboratory has been selected as a case study for evaluation of its intrinsic storage characteristics. In this context, the occurrence of the well-exposed Main Fault thrust zone provides an excellent opportunity to identify and describe the varied microstructural features (Laurich et al. 2014, 2016; Jaeggi et al. 2017) in order to evaluate their impact on the initial and future porosity/permeability characteristics of the host sediments.

Much has been published about physical deformation induced by tectonic activity in clay-rich shear zones (e.g. Agar et al. 1989; Labaume et al. 1997; Dehandschutter et al. 2005; Eiichi 2012; Ujiie et al. 2013) that can lead to the formation of gouge clusters (e.g. Rutter et al. 1986; Logan et al. 1992; Haines et al. 2013). Of interest here is the occurrence of such features in the Main Fault that potentially facilitate fluid flows interacting with varied host minerals, therefore implying chemical signatures depending on the type of fluids, as well as their temperature and chemical composition. In fact, such geochemical and isotopic tracing and dating information remains of limited application in fold/fault zones, mainly because of challenging sampling aspects (e.g. Schleicher et al. 2006; Sasseville et al. 2008). The sampling constraints are mainly due to the very fine size and therefore to the fragile fabric of the constitutive crystals (e.g. Vrolijk and van der Pluijm 1999; Warr et al. 2014).
A specific study was designed in the frame of Mont Terri scientific research projects to report on a combined geochemical and strontium ( $\mathrm{Sr}$ ) isotopic analysis of calcite and celestite intimately associated in varied microstructural features precisely located in the Main Fault of the Opalinus Clay in the Mont Terri rock laboratory (Techer et al. 2017). These varied microstructures identified and described by Laurich et al. (2014) represent drains that were used once by migrating fluids, as they contain infillings consisting mostly of calcite, but also of celestite. On the basis of electron microscope observations, these authors discussed their impact on the physical rock properties and deduced underlying deformation mechanisms. The objectives of the present geochemical and isotopic study became then a precise collection of these microstructures and a chemical identification of associated calcite and celestite infillings, in order to discuss the origin and nature of the interacting fluids, the extent of their interactions with the host minerals in and next to the microstructures of the Main Fault, as well as in those observed in the associated surrounding undeformed Opalinus Clay matrix and in the Hauptrogenstein, Passwang and Staffelegg Formations from above and below the Opalinus Clay, all taken as references. Clearly, the aim here is not examining the effects of fluid diffusion into the rock mass of the Opalinus Clay, but tracing potential fluid flows that could have migrated in the microstructures of the Opalinus Clay and the sedimentary formations around, with a special emphasis for the rock structures affected tectonically within the Main Fault and nearby.

\section{Summary of the geological setting}

The geological setting and structural evolution of the Mont Terri region is described in detail in Bossart et al. (2017), and Nussbaum et al. (2017). The Opalinus Clay of interest here consists of incompetent, silty and sandy shales of Aalenian/Toarcian stratigraphic age (ca. $174 \mathrm{Ma}$ ). It became a formation of major interest since it was selected for preliminary studies in the search of potential nuclear waste disposal sites in Switzerland, along with the excavation of the Mont Terri rock laboratory (Bundesamt für Energie 2008; Fig. 1a, b). Its argillaceous materials typically yield natural characteristics that appeared suitable for radioactive waste confinement with especially an extremely low hydraulic conductivity, low diffusion coefficients, and a fair retention ability of radionuclides (e.g. Hoth et al. 2007).

Also of concern here is the fact that the Mont Terri rock laboratory is intersected by a $0.8-5 \mathrm{~m}$ wide thrust zone called "Main Fault" that outcrops at different underground places in the laboratory. This blind thrust fault has been interpreted to result from a detachment at the base of the Opalinus Clay along the Rietheim Member of the 
a NNW

m. as 1

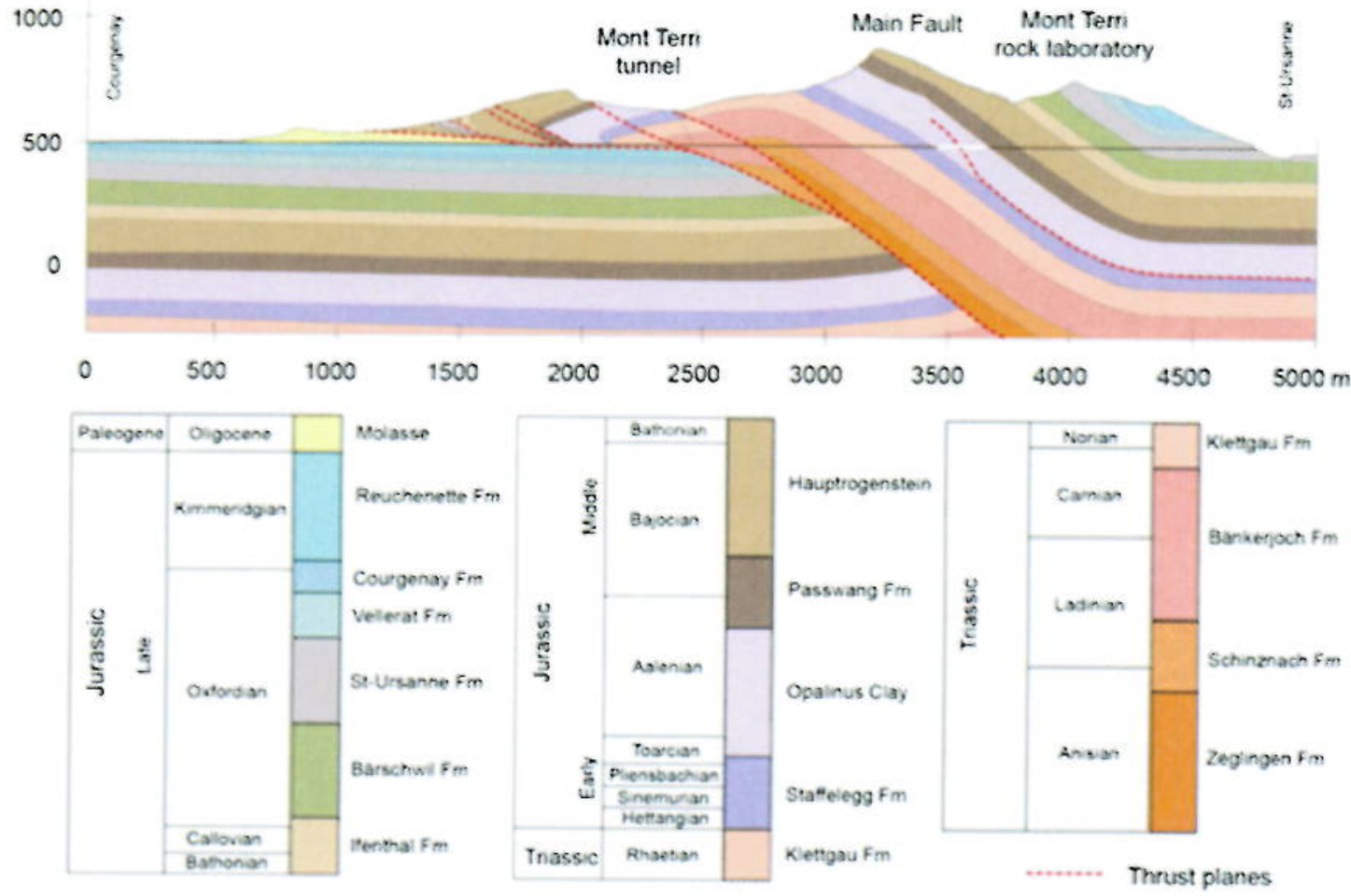

b

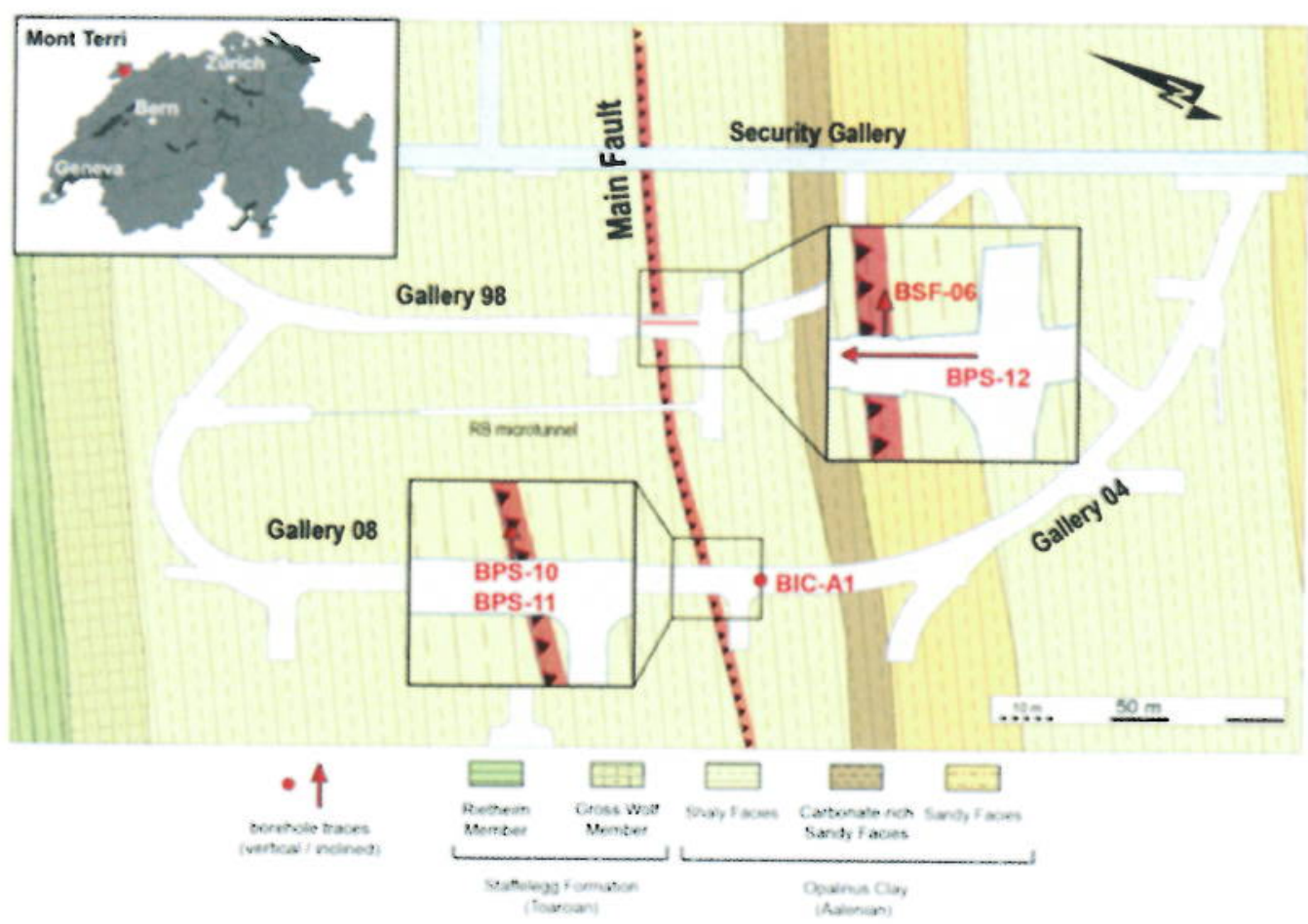

Fig. 1 Geologic context of the Mont Terri underground rock laboratory: a regional cross-section of the Mont Terri anticline and

Nussbaum et al. 2017); b geological map with the location of the the Main Fault with the location of the rock laboratory (from 


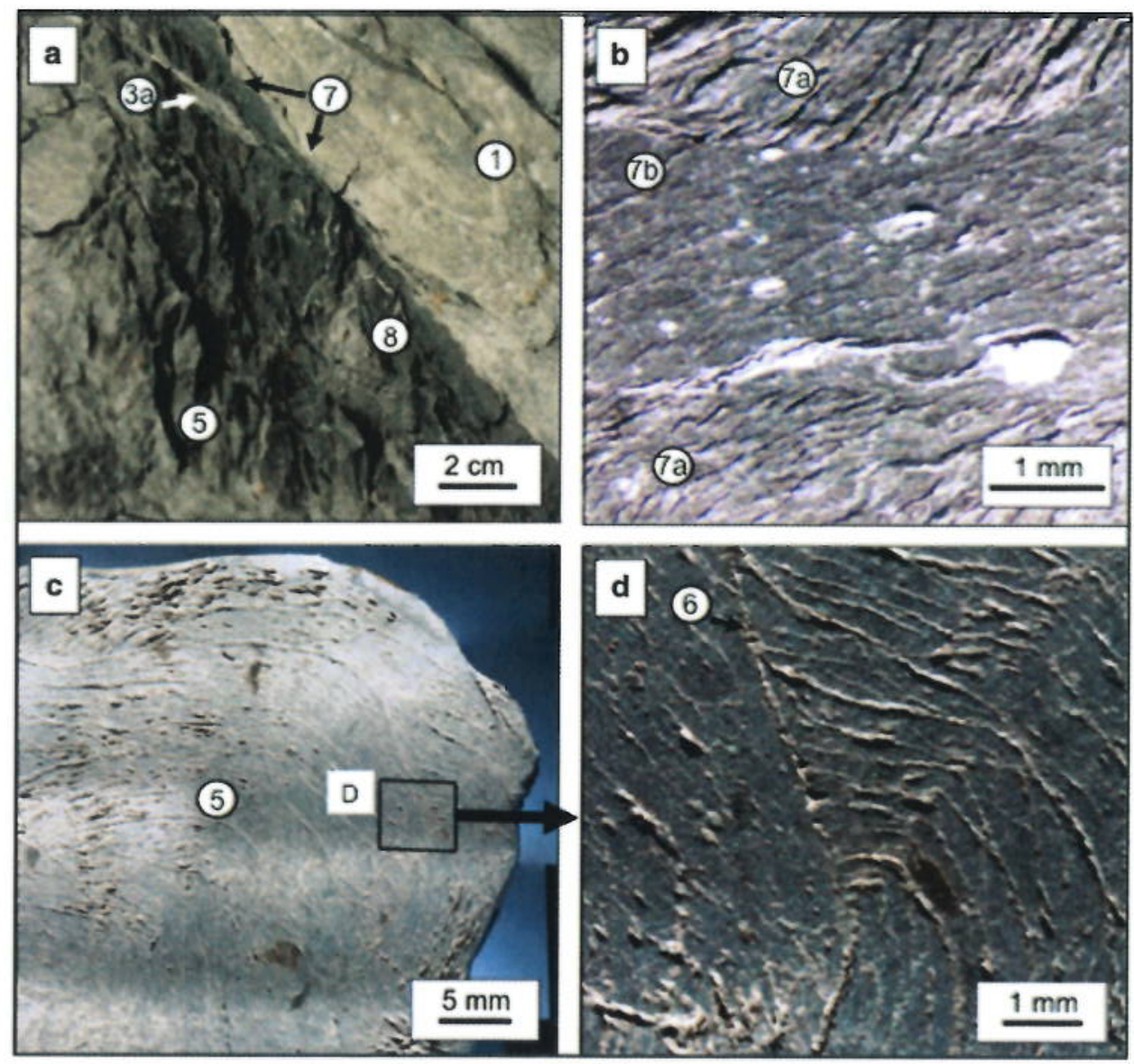

Fig. 2 a Photograph showing a detail from upper fault zone boundary of the Main Fault. The picture was taken at the outcrop in gallery 98 (viewing direction ENE). Numbers refer to samples types as given in Fig. 6 . Note the thin, continuous dark band of gouge (7) next to brighter undeformed material $(I)$ and the scaly clay next to (8) and away from the gouge (5). b Photograph (shaded light) of a water immersed gouge sample taken from the Main Fault outcrop in gallery 98 . Due to the water immersion, the foliation stands out,

Staffelegg Formation (Nussbaum et al. 2017; Fig. 1a). It provides an excellent opportunity to investigate incipient deformation and faulting, because of an easy access to extremely well preserved samples either cored into or outcropping at the gallery walls. This access allows a detailed evaluation of the impact of the microstructures on the natural confinement properties of the clay-rich mechanically deformed Opalinus Clay (e.g. Pearson et al. 2003; Bossart and Wermeille 2003; Nussbaum and Bossart 2008). The rocks of the fault zone consist of undeformed and highly strained volumes occurring next to each others (Laurich et al. 2014; Fig. 2a). Abundant in the outcrop of the Main Fault in the laboratory, the slickensides are associated with a network of micrometer-thin shear zones (Figs. 2, 3). They consist often of millimeter-sized calcite veins (Fig. 3), and more rarely of celestite veins. illustrating two different gouge types $(7 a$ and $7 b)$. The foliation also suggests high fabric intensity within the gouge. Note the sharp boundary between both types, $\mathbf{c}$ Photograph (shaded light) of a water immersed scaly clay sample from the Main Fault outcrop in gallery 98. Note the high variability in foliation orientation. d Detail of c showing bend bedding foliation (micro-fold) and discordant shear zones $(6)$

Nanometer-sized particles, also of clay type, are abundant on the slickenside surfaces and visible within the micrometer-thin shear zones (Figs. 3, 5). An increasing density of the slickensides characterizes the scaly-clay fabric (sensu Vannucchi et al. 2003; Fig. 2c, d), comprising a tangled anastomosing network of thin shear zones that

Fig. 3 a Photograph of a slickenside surface (top view). b On such a surface, note the dark, polished parts and the bright, ragged parts, being respectively treads and risers of the slickenside steps (Laurich 2015). The arrow gives the movement direction of the missing block. c Photograph of $\mathbf{b}$ combined with a SEM-EDX Ca mapping picture showing the occurrence of calcite at the risers. This suggests that the risers are in the stress-releasing zones, where Ca precipitation took place. d Side view on a micrometer-thin shear zone in a broken sample. Note that the bedding foliation is continuous up to the thin shear zone. $\mathbf{e}$ Is an inset of $\mathbf{d}$ illustrating that the shear zone width can be as small as only 10 th of $\mathrm{nm}$ 


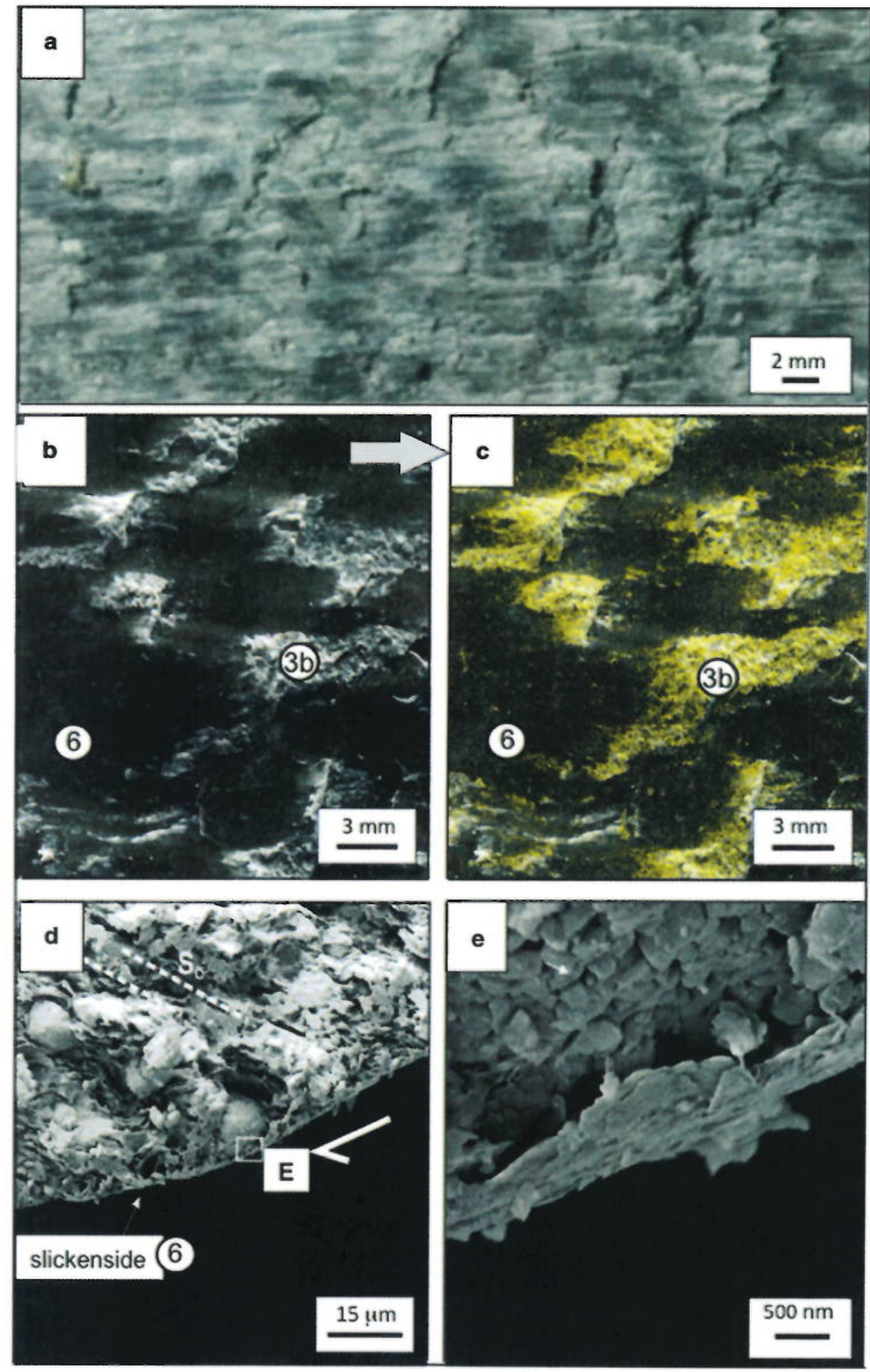


Fig. 4 a, b Photo and interpretative sketch of a waterimmersed gouge sample showing gouge (dark black) internal shear zones and grains, as-well as brighter wall rock clasts. The pictured sample was collected in the gallery 08 , at the limit between the upper and lower Main Fault segments (from Techer et al. 2017). c Slightly dissolved pyrite grains of the gouge. d Authigenic gypsum crystals of the gouge. The $\mathbf{c}^{\prime}, \mathbf{d}$ ' chemical spectra highlight the dominant occurrence of $\mathrm{S}$ in both and of $\mathrm{Fe}$ in the former and $\mathrm{Ca}$ in the latter

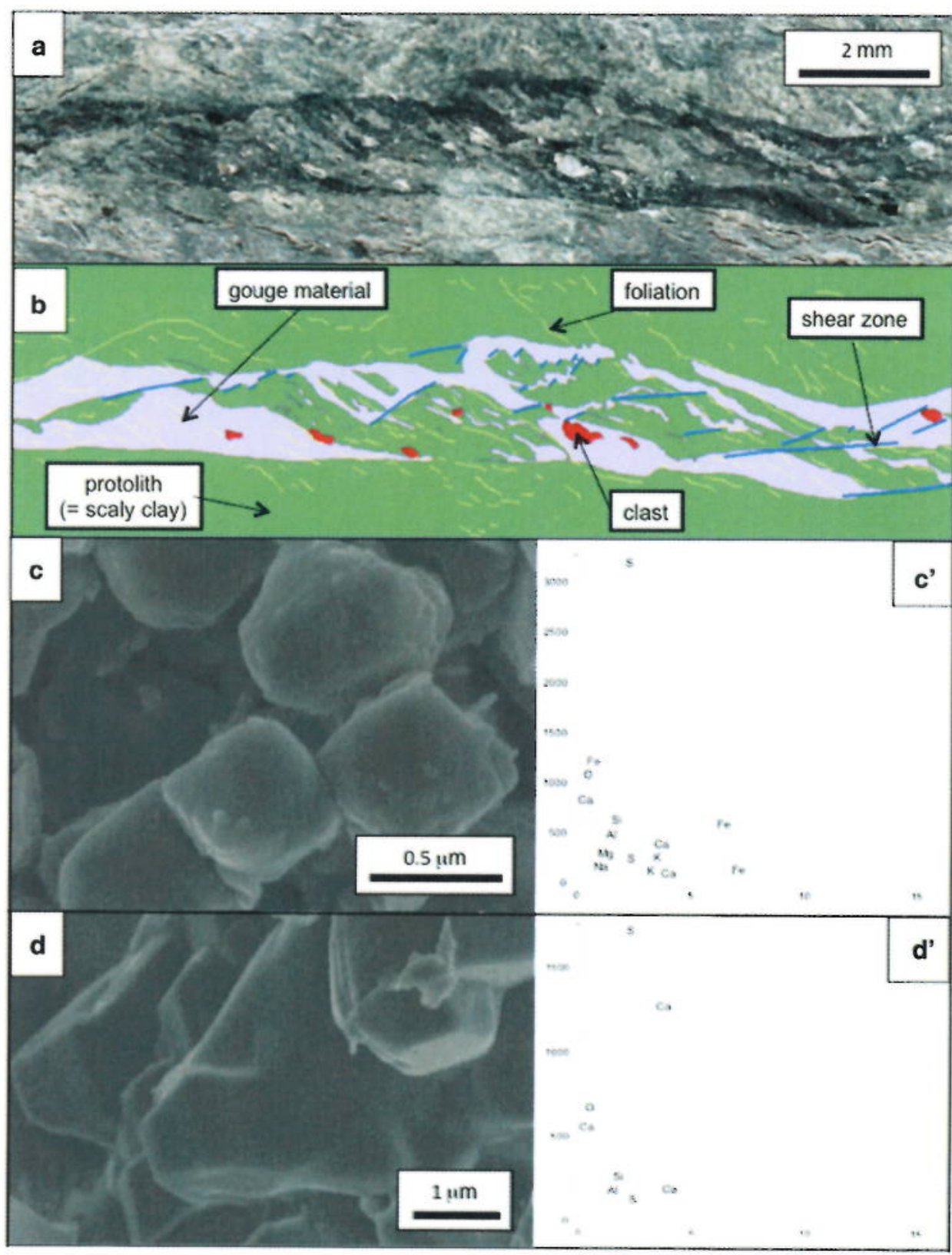

contain lens-shaped facies, almost undeformed microlithons (Laurich et al. submitted). The highest strain of the Opalinus Clay in the Main Fault is possibly localized in a thin $(<2 \mathrm{~cm})$ gouge layer at the upper fault zone boundary (Fig. $4 \mathrm{a}, \mathrm{b}$ ). This gouge layer is characterized by a strong foliation, isolated round clasts, grain-size reduction (Fig. 5a) and drastically lower calcite contents than in the nearby scaly clays (Laurich 2015).

Based on a description by Nussbaum et al. (2011) at a macro- and meso-scale, the following information is potentially relevant for the present review: (1) the tectonically undeformed rock fabric is heterogeneous and weakly foliated with a porosity of $8-24 \%$ (Nussbaum and Bossart
2008; Houben et al. 2013, 2014), (2) the fracture network and strain intensity are heterogeneous in the fault volume (Nussbaum et al. 2011), comprising zones with tiny fault gouges $(<1 \mathrm{~cm})$, shear bands, micro-folds, striated fault planes, all next to apparently undeformed materials, (3) based on paleo-stress analyses of slickenside striae, the kinematic analysis outlines sub-horizontal, striking NNWSSE in a reverse faulting mode (Nussbaum et al. 2011), and (4) the paleo-fluid flux estimated from calcite and celestite veins in the Rock Laboratory (Pearson et al. 2003) suggests advective flows (Nagra 2008).

The geochemical information available in internal reports from partner organizations of the Mont Terri 

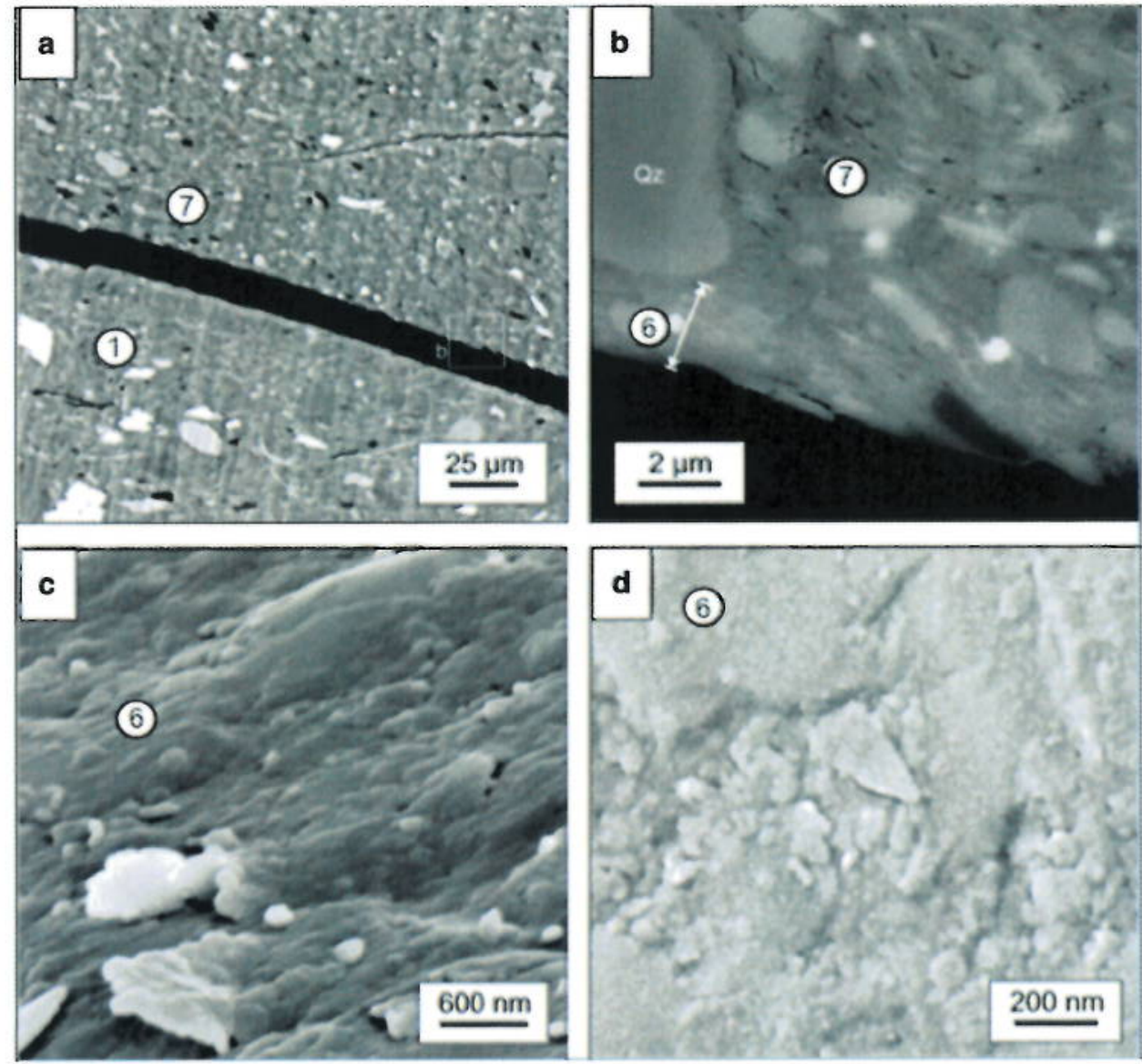

Fig. 5 a BIB-SEM micrograph showing a gouge (upper sample part) in contact with undeformed material (lower part) separated by an open void (=sampling artifact). Compared to undeformed material, the gouge has a smaller grain size, contains more rounded grains and yields higher fabric intensity. b Is a detail of the micrograph

Consortium contains petrographic and geochemical results of vein infillings from the Main Fault, diffuse calcite from undeformed Opalinus Clay reference materials (Degueldre et al. 1998; Lancelot 2001; Pearson et al. 2001), and porewaters (Pearson et al. 2003). The calcite and celestite veins described by de Haller et al. (2014) within the whole Opalinus Clay matrix are thin $(<1 \mathrm{~mm}$ thick) and yield fibrous crack-seal microstructures that indicate syntectonic precipitation. These authors consider that the Opalinus Clay acted as a seal for migrating fluid flows during most of its history except during the tectonic episode that developed the Main Fault.

\section{Sampling and analytical context}

Most sampling of the present study was completed in the fault zone, in a precise petrofabric context detailed by Laurich et al. (2014) with a summarizing view of the a picturing the gouge's boundary to be a micrometer-thin shear zone of shears parallel to nanometer-sized clay particles. c, d Highresolution SEM micrographs of slickenside surfaces covered by clay particles having sizes of a few 10th of nanometers. $c$ Oblique view of the same, and dop view

selected features and their relationships, especially in the nearby BSF-06, BPS-12 and BIC-A1 cores (Fig. 1b). A synthetic sketch explaining the relationship among the features analyzed for their chemical characteristics by Techer et al. (2017; Fig. 6) has also been drafted, whereas further information about the core drillings is available in Nussbaum et al. (2006). Collection of the selected vein infillings consisting of calcite $\left(\mathrm{CaCO}_{3}\right)$ or celestite $\left(\mathrm{SrSO}_{4}\right)$ was as precise as possible by careful sorting out under a binocular. Characterized by different reactivity to acid leaching, calcite being easily dissolved even by a dilute acid and celestite being quite insoluble in acids, a sequential leaching procedure was applied to the picked-up crystals that were first crushed gently before acid reaction, for discrimination of their respective elemental and $\mathrm{Sr}$ isotopic data. The initial leaching consisted of a $1 \mathrm{~N} \mathrm{HAc}$ leaching for $10 \mathrm{~min}$ to extract the soluble calcite phase, the leachate being recovered by centrifugation, split in two, and used for either $\mathrm{Sr}$ separation and isotope determination 


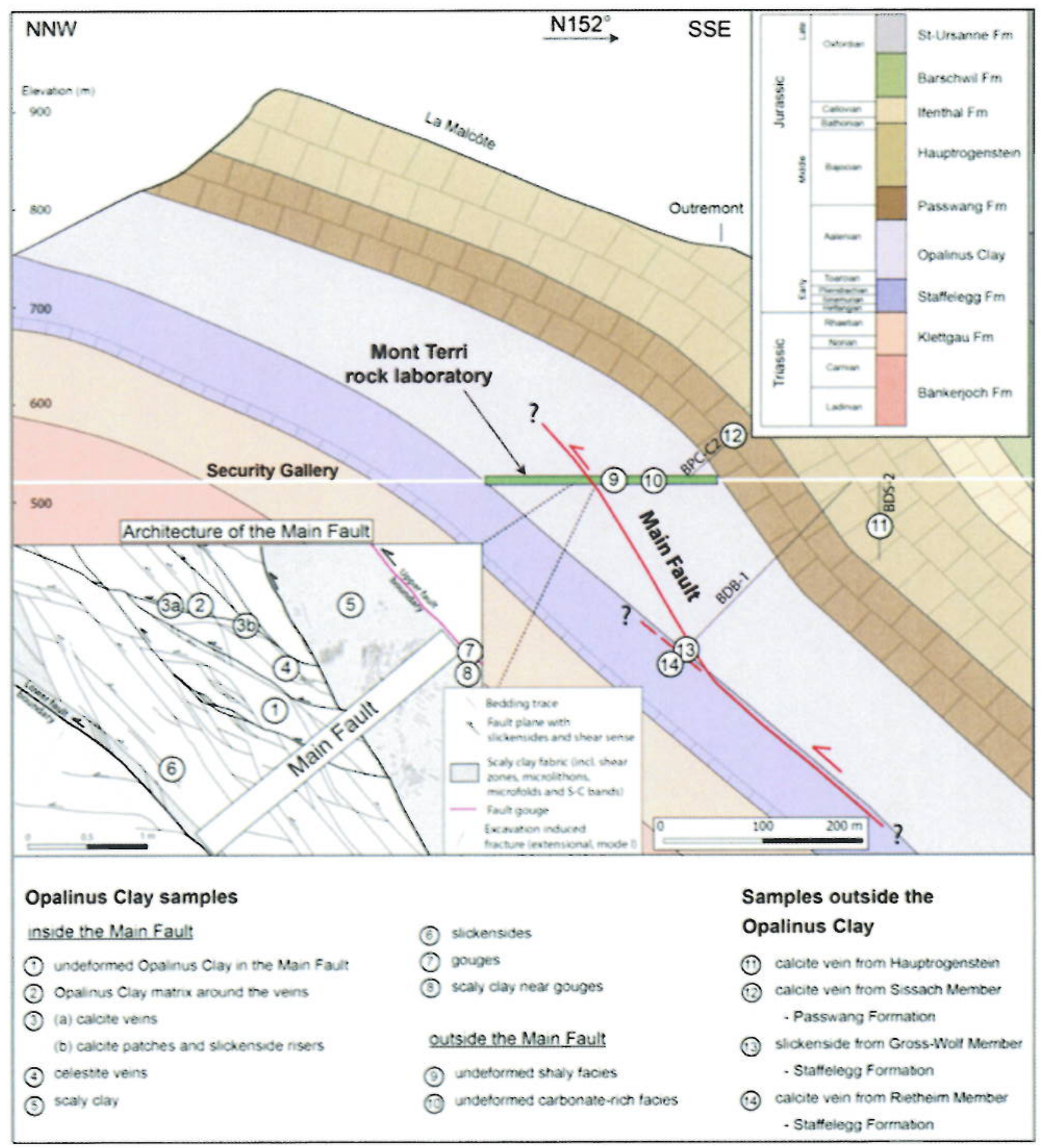

Fig. 6 Geological cross section around the Mont Terri rock laboratory. The Main Fault and the spatial, lithological and structural location of the 14 sample types analyzed by Techer et al. (2017) and discussed here is shown

or elementary analysis. In the case of the veins consisting of both calcite and celestite, the leftover celestite powder after gentle leaching was dissolved by a mixture of $7 \mathrm{~N}$ $\mathrm{HNO}_{3}, 6 \mathrm{~N} \mathrm{HCl}$ and $12 \mathrm{~N} \mathrm{HF}$ in a microwave equipment (ThermoFisher Thos One) at high temperature and under pressure. All obtained solutions were evaporated and dissolved again in a few drops of $\mathrm{HNO}_{3}$. It is probably appropriate to recall two methodological aspects at this point: (1) initial gentle acid leaching as used here for calcite dissolution does not affect the $\mathrm{Sr}$ isotopic system of 
Fig. 7 Boxplot presentation of major elemental contents. The long central rectangles of the boxes represent $75 \%$ of their contents with a transversal bar for the average of these data, the highest and lowest values being outlined by the circles above and below. In the sample description, the numbers in brackets give the number of analyzed samples (from Techer et al. 2017)
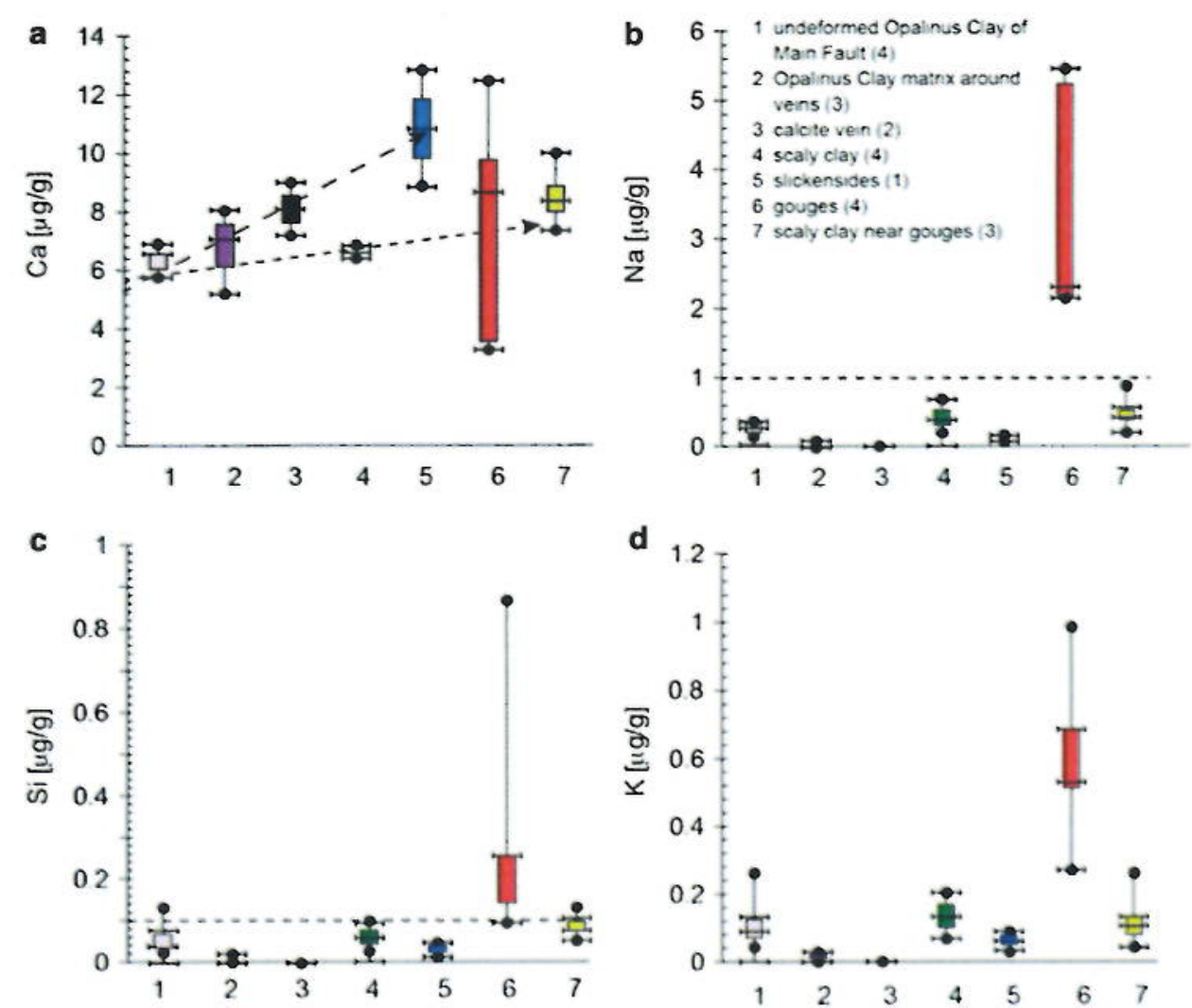

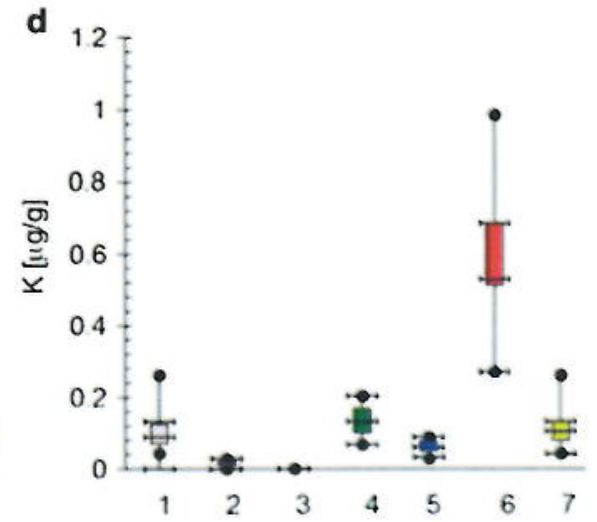

potentially associated alkali-bearing minerals that therefore does not supply any radiogenic ${ }^{87} \mathrm{Sr}$ to the leachates (Clauer et al. 1993), and (2) leaching of the Opalinus Clay matrix dissolves the diffuse calcite but also removes chemical elements adsorbed potentially on the clay particles (Lerouge et al. 2010). However, this is not of a real concern here as the $\mathrm{Sr}$ adsorbed on the clay materials yields necessarily the same ${ }^{87} \mathrm{Sr} /{ }^{86} \mathrm{Sr}$ ratios as the calcite crystals, both deriving from the same connate fluids, and secondly the amount of $\mathrm{Sr}$ removed from clay particles is significantly lower than that of calcite, which is a main sedimentary $\mathrm{Sr}$ carrier.

The $\mathrm{Sr}$ separation was completed on Eichrom $\mathrm{Sr}$-resin following Pin et al.'s (2003) procedure. After separation on a resin column, the ${ }^{87} \mathrm{Sr} /{ }^{86} \mathrm{Sr}$ isotopic ratios were measured by solid-source thermal ionization mass spectrometry. The contents of $\mathrm{Ca}$ and $\mathrm{Sr}$, as well as of $\mathrm{Si}, \mathrm{Al}, \mathrm{Mg}, \mathrm{Fe}, \mathrm{Mn}, \mathrm{Ti}$, $\mathrm{Na}, \mathrm{K}$ and $\mathrm{P}$ from various leachates were determined by ICP-AES/MS following Samuel et al.'s (1985) procedure.

\section{Summary of the available geochemical database}

Details of the elemental and ${ }^{87} \mathrm{Sr} /{ }^{86} \mathrm{Sr}$ results are available elsewhere (Techer et al. 2017); they were not duplicated here on purpose. In summary, significant variations of most analyzed major elements were obtained for the dissolved calcite dispersed in the Opalinus Clay matrix, and for the infillings of the scaly clays, slickensides, veins and gouges. These varied contents suggest, together with the $\mathrm{Ca} / \mathrm{Sr}$ ratios, different elemental compositions for the "initial" diffuse calcite of the undeformed Opalinus Clay in the Main Fault, and for that of the tiny structural features on one hand, and of the gouges on the other, for instance on the basis of the $\mathrm{Ca}, \mathrm{Na}, \mathrm{Si}$ and $\mathrm{K}$ contents (Fig. 7). The fluids that interacted with calcite of the veins are clearly different from those that interacted with the diffuse calcite of the undeformed Opalinus Clay matrix and with those of the gouge calcite that all outline specific chemical compositions. In summary, the fluids that flew through the gouges generated carbonates with a different striking chemical composition, even if their $\mathrm{Ca} / \mathrm{Sr}$ ratios remain in the general range of the other studied features. For instance, the gouge leachates are significantly enriched in $\mathrm{Si}, \mathrm{Al}$ and alkalis, especially $\mathrm{Na}$, relative to those of the other features (Fig. 8). The infillings of the veins and the diffuse calcite of the Opalinus Clay matrix around them yield very low contents in $\mathrm{K}$, whereas higher $\mathrm{K}$ contents were detected in diffuse calcite from undeformed matrix outside the Main Fault, in those of the slickensides and the scaly clays. The highest $\mathrm{K}$ contents were detected in the gouge leachates. Most $\mathrm{Si}$ and $\mathrm{Al}$ contents of the leached 

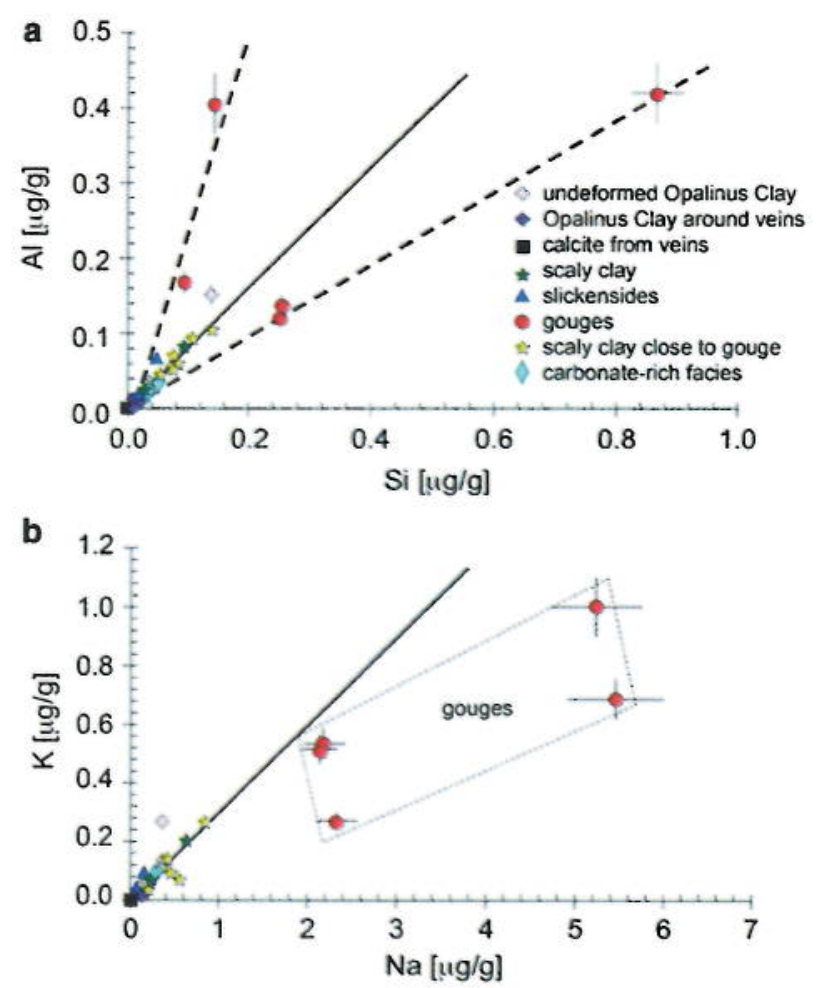

Fig. 8 Correlations between the $\mathrm{Al}$ and $\mathrm{Si}$, and between the $\mathrm{K}$ and $\mathrm{Na}$ contents of the infillings from varied microtectonic structures. In the upper diagram, the full line outlines the $\mathrm{Si}-\mathrm{Al}$ correlation for all infillings except those of the gouges, while the lower dashed line outlines the $\mathrm{Si} / \mathrm{Al}$ ratio of potential illite authigenesis. In the lower $\mathrm{K}$ vs. Na diagram, the data points of the gouge infillings plot all outside the line including the data of the other infillings (from Techer et al. 2017)

calcite of all features plot along a trend with a correlation factor of 1 , whereas those of the gouges are clearly outside (Fig. 8). Noteworthy are also the data points of the $\mathrm{Si}$ and $\mathrm{Al}$ contents of the calcite from gouges that yield ratios identical to the theoretical $\mathrm{Si} / \mathrm{Al}$ ratio of illite, making an authigenic crystallization plausible (Rieder et al. 1998), even if not yet precisely identified and described. Also, the diffuse calcite of the Opalinus Clay matrix sampled either away from microstructures, or in the scaly clays, yields significantly higher $\mathrm{Ca} / \mathrm{Sr}$ ratios $(>100)$ than the leachates of the "fluid-flow" sites, that is to say of the calcite from veins, matrix around the veins, slickensides and gouges (<100; Fig. 9a).

The distribution of the rare earth elements (REE) of a mineral or a rock is generally displayed relative to the same elements of a reference mineral or rock (e.g. Taylor and McLennan 1985). The observed variations of the individual REEs can then be calibrated to those of the chosen reference. If the ratio of each is then at 1 , no fractionation occurred, while it did when the ratio is either below or above unity. In the former case, the considered REE is at a lower amount than in the reference, and in the latter it is concentrated in the sample relative to the reference. Here, the REE contents of the infillings from varied microstructures are either enriched or depleted relative to the diffuse Opalinus Clay calcite. In sum, the contents display three shapes relative to that of the reference (Fig. 10a, b, d, e): (1) an almost flat distribution for some scaly clays and the carbonated sandy Opalinus Clay facies, meaning that no major fractionations occurred in these mineral phases; (2) an open "V" shaped distribution with a slightly decreasing repartition for the light REEs (LREEs) from La to Gd followed by an increase from $\mathrm{Tb}$ to $\mathrm{Yb}$ and $\mathrm{Lu}$ in the veins and slickensides, the Opalinus Clay matrix around the veins, as well as in the vein calcite of the sediments above and below the Opalinus Clay (Fig. 10c-e, underlined in blue), and (3) a pattern with ups and downs along a continuous increase of the LREEs from La to Sm, a decrease from $\mathrm{Sm}$ to $\mathrm{Lu}$ for the gouge samples, all characterized by various positive $\mathrm{Sm}$ anomalies, and for the diffuse calcite of two scaly clays collected close to a gouge (Fig. 10a, b, underlined in red). Varied fractionations obviously occurred in the samples corresponding to the cases 2 and 3 . In summary, one type of fluid seems to have migrated through the tiny millimeter-sized structural features (veins and slickensides) of the Main Fault, also diffusing somehow into the matrix around the veins and the scaly clays. This is also the case for the veins of the sediments surrounding the Opalinus Clay that yield also a positive La anomaly. Conversely, the REE patterns of the gouges are clearly different with an intriguing positive $\mathrm{Sm}$ anomaly that is known to be lacking in the pure mineral world. Scaly clay aggregates yield REE patterns similar to those of the gouges when collected next to it, while scaly clays taken farer away from gouges yield patterns that are similar to those of the undeformed Opalinus Clay.

Comparing the ${ }^{87} \mathrm{Sr} /{ }^{86} \mathrm{Sr}$ ratios of the infillings from varied microstructural features of the Opalinus Clay used here and determined by Techer et al. (2017), to data of calcite separates from in- and outside the Main Fault published by Pearson et al. (2003) and de Haller et al. (2014) is of interest and importance for the global interpretation of the whole database (Fig. 9b). Almost all ${ }^{87} \mathrm{Sr} /{ }^{86} \mathrm{Sr}$ ratios from these two publications range narrowly between 0.70768 and 0.70778 . Only those of the diffuse calcite of the matrix from outside the Main Fault are significantly above this overall narrow range. This repartition calls for two observations: (1) the ${ }^{87} \mathrm{Sr} /{ }^{86} \mathrm{Sr}$ ratios of the diffuse calcite from undeformed Opalinus Clay in the Main Fault are closer to the ${ }^{87} \mathrm{Sr} /{ }^{86} \mathrm{Sr}$ ratios of the microstructures, being even within the same range, than to those of the diffuse calcite from matrix outside the fault, and (2) the infillings of the veins from outside the Main Fault contain Sr with ${ }^{87} \mathrm{Sr} /{ }^{86} \mathrm{Sr}$ ratios that are within the dispersion range 
Fig. 9 Boxplots of a the $\mathrm{Ca} / \mathrm{Sr}$ ratio from infillings of the varied microtectonic structures, b the ${ }^{87} \mathrm{Sr} /{ }^{86} \mathrm{Sr}$ ratio of the same infillings and from those analyzed by de Haller et al. (2014). For the explanations of the boxplots, see Fig. 7 (from Techer et al. 2017)
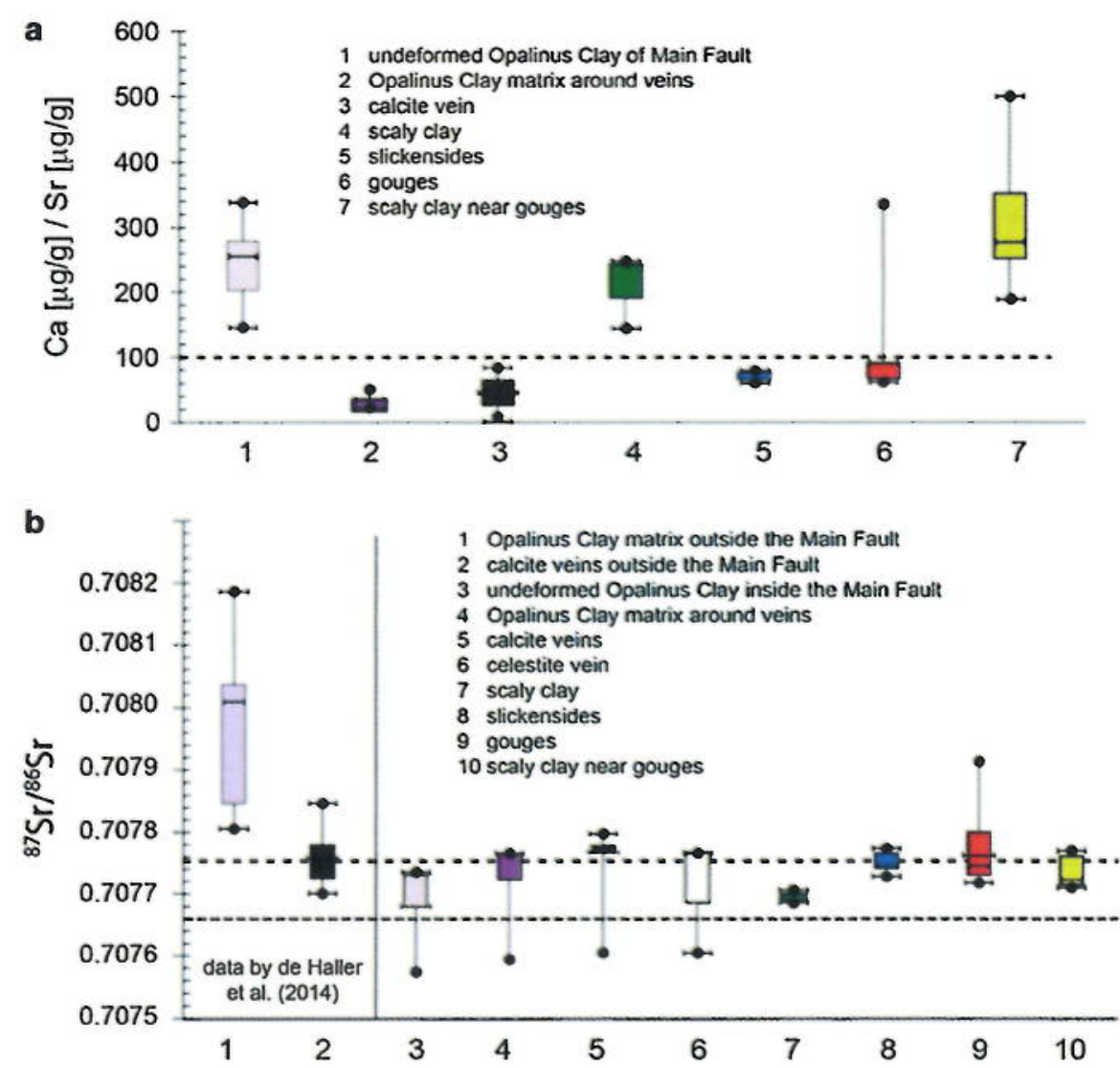

of those of the microstructural infillings within the fault. The undeformed Opalinus Clay within the Main Fault contains leachable ${ }^{87} \mathrm{Sr} /{ }^{86} \mathrm{Sr}$ ratios close to those of the microstructures of the fault itself, suggesting that the fluids that flew within the microstructures apparently diffused also discretely into the whole rock volume of the fault, somehow "contaminating" it locally. In fact, as already mentioned, leachates that include the diffuse calcite might also contain chemical elements adsorbed at the detrital silicates of the matrix and of the sediments below and above the Opalinus Clay. In fact, they yield ${ }^{87} \mathrm{Sr} /{ }^{86} \mathrm{Sr}$ ratios within the range of those from calcite infillings of the Main Fault microstructures.

The correlation between the ${ }^{87} \mathrm{Sr} /{ }^{86} \mathrm{Sr}$ and the $\mathrm{Ca} / \mathrm{Sr}$ ratios (in wt $\%$ ) of calcite veins, undeformed matrix close to and away from veins sketches a wide area (Fig. 11). This discrepancy between the narrowly ranging ${ }^{87} \mathrm{Sr} /{ }^{86} \mathrm{Sr}$ ratios of the leachable minerals of most microstructures and the widely scattered ${ }^{87} \mathrm{Sr} /{ }^{86} \mathrm{Sr}$ ratios of the diffuse calcite from undeformed Opalinus Clay was striking and unexpected. In fact, the conceptual hypothesis was rather based on the occurrence of a homogeneous sedimentary reservoir represented by the diffuse calcite from undeformed matrix and by a less homogeneous reservoir external to the Opalinus Clay, mixing more or less with earlier calcite dissolved in the microstructures and recrystallizing after mixing. This is clearly not the case. The average ${ }^{87} \mathrm{Sr} /{ }^{86} \mathrm{Sr}$ ratio of the end-member characterizing the moving "fluid-flow" is at $0.70774 \pm 0.00001$ $(2 \sigma)$, which excludes any potential interference of porewaters with higher ${ }^{87} \mathrm{Sr} /{ }^{86} \mathrm{Sr}$ ratios, for instance from the Opalinus Clay host rocks or from older sedimentary systems, especially from Triassic Muschelkalk stratigraphic formation as stipulated elsewhere (de Haller et al. 2014). In fact, the secular variation of the seawater $\mathrm{Sr}$ of this Triassic epoch only yields a few values that are significantly scattered above 0.7078 (Fig. 13a; McArthur et al. 2001). Occurrence of Triassic evaporate-type sulfates to assess the observed celestite precipitation in the veins and slickensides can therefore be excluded. Also, none of the $\mathrm{Sr}$ from infillings of the varied microstructures of the Opalinus Clay could originate either from carbonate-rich layer, or from surrounding sediments. Also to be mentioned are the ${ }^{87} \mathrm{Sr} /{ }^{86} \mathrm{Sr}$ ratios of the vein infillings occurring in the sediments above and below the Opalinus Clay that are within the range of the ${ }^{87} \mathrm{Sr} /{ }^{86} \mathrm{Sr}$ ratios of the infillings from Opalinus Clay microstructures. This similarity suggests that the same fluids migrated also along the 
Fig. 10 REE distribution patterns of the veins, the slickensides, the gouges, the scaly clays of the Opalinus Clay (OPA) and the surrounding sediments (from Techer et al. 2017)

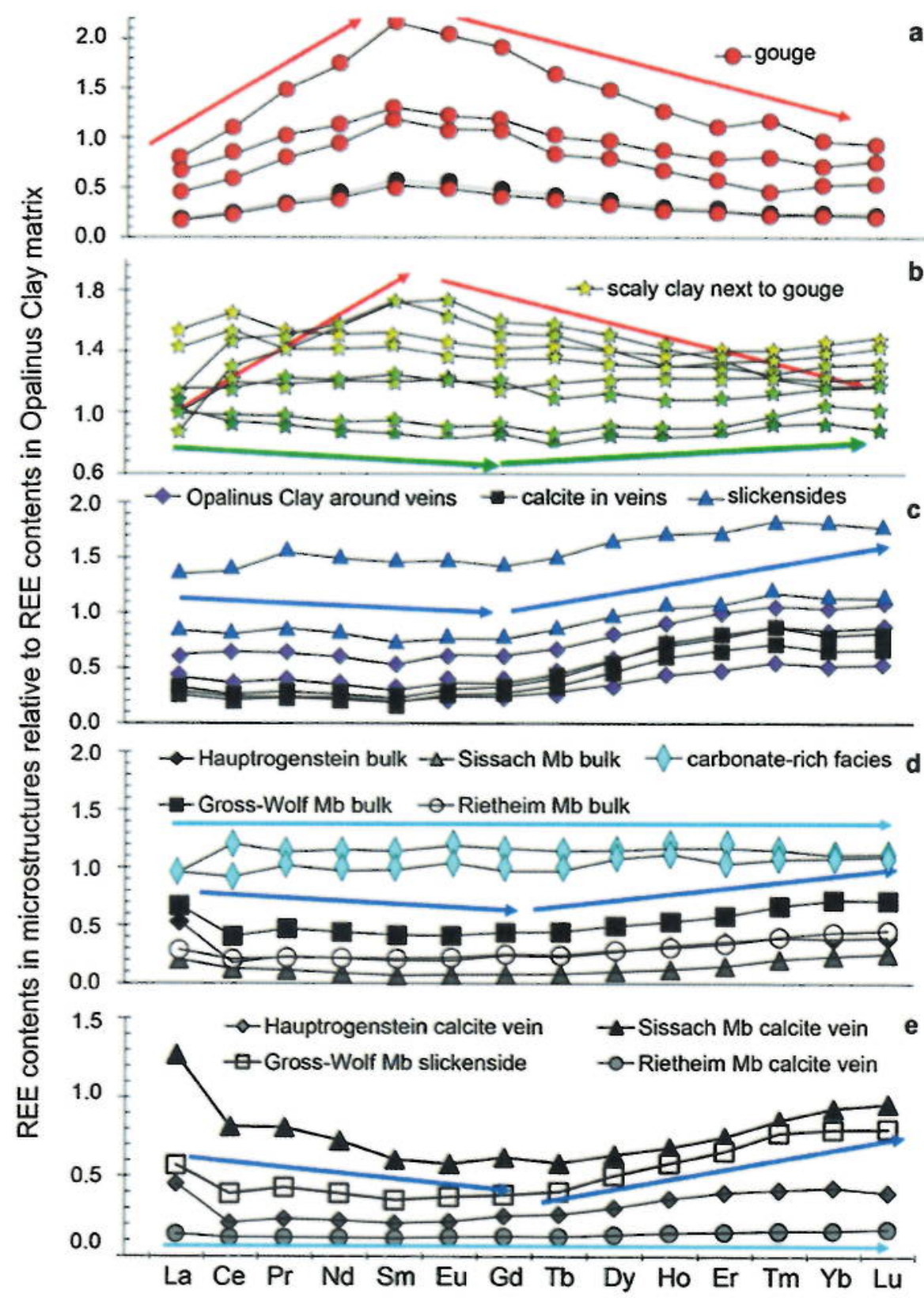

tectonic features that were observed outside the Main Fault, which is confirmed, in turn, by the distribution of the REEs (Fig. 10).

\section{Discussion}

The goal set here is an integration of the chemical information into the microstructural description for a determining evaluation of the structural evolution of the Main Fault in the Opalinus Clay of the Mont Terri rock laboratory. This evaluation includes two aspects that will be addressed successively and combined in a final wrap up, namely: (1) how useful can a geochemical database be in interpreting a structural context, and (2) when and how did the tectonothermal event proceed on the basis of the combined stratigraphic, micro-structural and geochemical information.

\subsection{The geochemical information}

The relationship between the ${ }^{87} \mathrm{Sr} /{ }^{86} \mathrm{Sr}$ and $\mathrm{Ca} / \mathrm{Sr}$ ratios of the leachable carbonates from undeformed Opalinus Clay matrix and from varied microstructures of the Main Fault was initially tested to provide new information about how 
Fig. 11 Relationship between the ${ }^{87} \mathrm{Sr} /{ }^{86} \mathrm{Sr}$ and the $\mathrm{Ca} / \mathrm{Sr}$ ratios of the infillings from microstructural features and matrices analyzed by Techer et al. (2017). The yellow diamonds to the right define the analytical area of the undeformed Opalinus Clay OPA (from Techer et al. 2017)

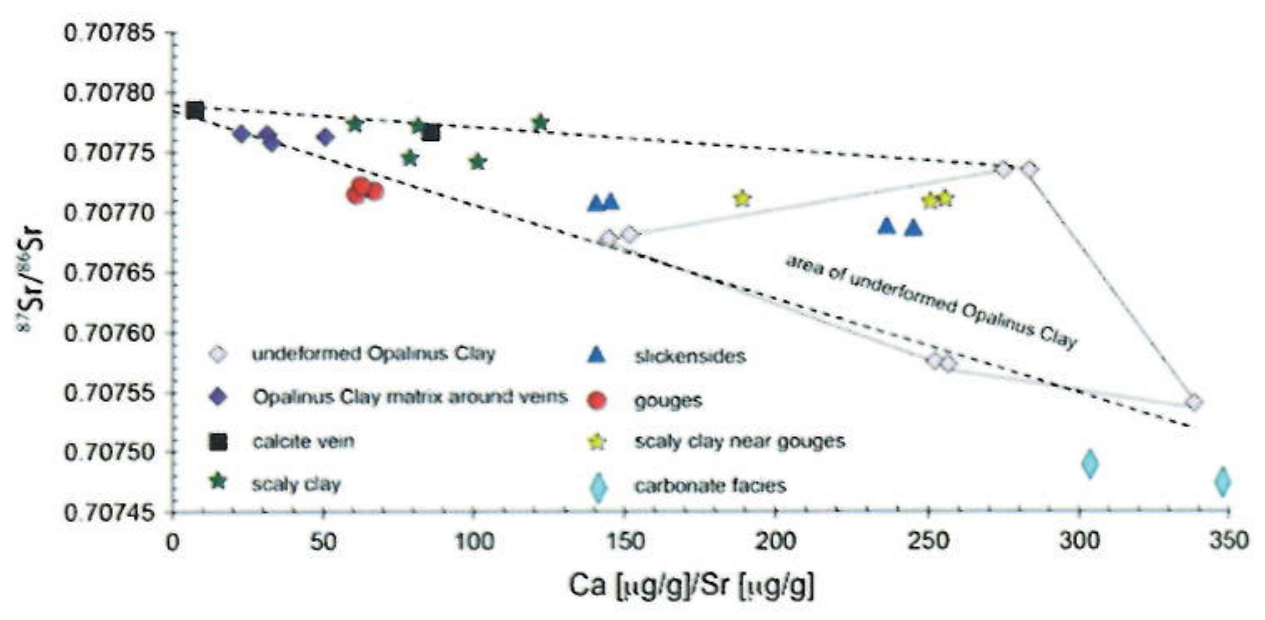

the fault evolved. This combination is quite complex, as a simple two end-member mixing cannot be applied straight: in fact, more than one linear trend can be drawn through the data points of the concerned diagram (Fig. 11). In fact, it is the diffuse calcite of the undeformed Opalinus Clay that yields an unexpectedly scattered ${ }^{87} \mathrm{Sr} /{ }^{86} \mathrm{Sr}$ ratio, making a mathematical evaluation difficult for a hypothetical mixing with $\mathrm{Sr}$ of the migrating fluids. This preliminary observation is confirmed by determinations published by de Haller et al. (2014; Fig. 9b) that showed dispersed ${ }^{87} \mathrm{Sr} /{ }^{86} \mathrm{Sr}$ ratios for the leachable undeformed Opalinus Clay from outside the Main Fault, and a narrowly ranging ${ }^{87} \mathrm{Sr} /{ }^{86} \mathrm{Sr}$ ratio for the vein infillings of the matrix similar to those analyzed by Techer et al. (2017) and discussed here.

The best evaluation of the geochemical input for a valuable explanation of the Main Fault structural processing starts with a comparison of the chemical composition from infillings of the different microstructures. As shown by the elemental contents in the leachates from undeformed matrix, slickensides, veins, scaly clays and gouges, fluids that interacted with the vein infillings are clearly different from those that interacted with the diffuse calcite of the undeformed Opalinus Clay, in addition to an even more specific composition for the leachates from gouges (Fig. 7). This difference calls for a preliminary statement, namely that water diffusion into the rock mass of the Opalinus Clay (=diffuse calcite in the undeformed matrix) and water percolation (advection) in the identified microstructures (=calcite infillings induced from interaction with the migrating fluids) result from different processes that probably occurred at different periods. Furthermore, the heterogeneous ${ }^{87} \mathrm{Sr} /{ }^{86} \mathrm{Sr}$ ratio of the diffuse calcite from Opalinus Clay clearly excludes any contribution of the associated connate waters to the flow waters of the microstructures. The analytical variation of their ${ }^{87} \mathrm{Sr} /{ }^{86} \mathrm{Sr}$ ratio being one hundred times higher, at $1 \times 10^{-3}$, than that of the homogeneous ${ }^{87} \mathrm{Sr} /{ }^{86} \mathrm{Sr}$ ratio of the flow fluids, which is only of $1 \times 10^{-5}$, no mixing of connate waters with such variable $\mathrm{Sr}$ isotopic composition can provide a mixture characterized by a homogeneous $\mathrm{Sr}$ isotopic signature, whatever the envisioned mixing.

As already mentioned, the fluids flew in a different chemical context in the gouges than those of the other microstructures, being even possibly of another origin. These different fluids had a tendency to dissolve calcite instead of precipitating it, with the leftover having a different chemical composition, even if the $\mathrm{Ca} / \mathrm{Sr}$ ratio that characterizes the mineral type rather than the origin of the fluids remained in the general area of all studied microstructures. The chemical compositions of the gouge infillings yield higher $\mathrm{Al}$ and $\mathrm{Si}$ contents than those of the infillings from any of the other microstructures (Fig. 8). The $\mathrm{Si}-\mathrm{Al}$ data points of three gouge infillings plot also within the theoretical $\mathrm{Si} / \mathrm{Al}$ ratio of illite, making its crystallization potentially plausible as postulated by Rieder et al. (1998). The second determining elemental information is in the $\mathrm{Ca} /$ Sr ratio of the gouge infillings that is lower than 100 , which is the range of those from veins and slickensides, whereas the leachable undeformed Opalinus Clay sampled either away from microstructures or from scaly clays yields $\mathrm{Ca} / \mathrm{Sr}$ ratios higher than 100 (Fig. 9a). The $\mathrm{Ca} / \mathrm{Sr}$ ratio of the gouge leachates is also more widely scattered in a 1-5 range. On top of this chemical information tending to identify the occurrence of a different fluid, scanning-electron microscope observations also allowed identification of pyrite grains in the gouge rock chips that were clearly dissolved next to large patches of idiomorphic gypsum (Fig. 4c, d). Of course, it can always be argued that pyrite alters naturally by oxidation next to recent underground excavations and that it might facilitate precipitation of gypsum. In the present case, the samples were recovered from dry drillings away from gallery excavations, and the gypsum precipitation can be observed as large, idiomorphic and well-organized crystals.

The REE distribution patterns of the infillings from microstructures and those of the diffuse calcite from 
undeformed Opalinus Clay support the fact that one type of fuid seems to bave migrated through most tiny millinetersized structural features (veins and stickensides) of the Main Fault, atso diffusing somehow into the matrix around the veins. The sane fluids or of a sinilar type migrated also along the veins of the sediments occurring next to the Opalinus Clay, depositing identical infillings in similat features. Conversely, the REE patterns of the gouge infillings are noticeably different with an intriguing and variable positive Sm anomaly that has never been reportod in pure minerals, to the best of our knowledge. This Sm anomaly is another index that external finids had to intrude the gouges at a given time is such a $\mathrm{Sm}$ positive anomaly cannot develop in a closed chemical system of mineral origin. This additional fuid had to be mixed wilh those generated internally by an expected pressure-solution process. Interestingly, the REE patterns of the scaly clays are either similar to those of the diffuse calcite from matrix, or to those of the gouges, depending probably on their precise sumpling location and their mineral composition. In any case, they confim the occurrence of the just-mentioned supplementary external fluid. As the intimate details of the gouges are difficult to distinguish with a blank eye, it is most probable that the collected scaly clays consist, in fact, of more or less structurally undeformed Opalinus Clay that is more or less affected chemically. Depending on the impact of the migrating fluids, they might differ and their leachates mimic those from nearby gouges (Figs. 2b, 4, 5a).

\subsection{Summary of the evolution of the Opalimus Clay matrix}

The evolution of the Opalinus Clay integrates sedimentary, diagenetic and tectonjc events since deposition in a marine environment about $174 \mathrm{Ma}$ ago (Middle Jurassic), the successive events being identified and integrated into a summarizing sketch (Fig. 12). After deposition, the entire sedimentary pile including the Opalinus Clay was progressively buried and subjected to a Late Jurassic subsidence about $150 \mathrm{Ma}$ ago that resulted from a widespread rifting described all over Europe (e.g. Cathelineau et al. 2012 and references therein). After that subsidence, gentle burial continued until about $120 \mathrm{Ma}$ (Early Cretaceous) ago to a sediment thickness of about $1350 \mathrm{nt}$. A quiescent period followed until an uplift of the whole sedimentary sequence that leaded to the erosion of the Cretaceous and Late Jurassic sediments above the Opalinus Ctay. At about 40-28 Ma ago (second half of the Paleogene), a new subsidence that did not necessarily affect all regionally dispersed basins resulted from a renewed rifting activity with a final uplift that brought the Opalinus Clay back to a depth of about $500 \mathrm{~m}$ (Mazurek et al. 2006). This subsidence was obviously only limited to some sub-basins, probably not reaching the study area. The Delémont Basin of interest here was most probably in a backbulge Alpine position, being only transgressed during the Lower Oligocene (Berger et al. 2005a).

\subsection{Intrieacy of the sedimentological evolution of and the geochemical signatures in the Opalinus Clay}

During deposition of the Opalinus Clay, seawater and biologic remmants were trapped in the sediments with probable crystallization of a diffuse sedimentary calcite. Most of this seawater was expelled afterwards probably during progressive burial, while mineral and biologic relicts remained within the sediments. On the basis of the secular variation of the ${ }^{87} \mathrm{Sr} /{ }^{86} \mathrm{Sr}$ ratio of seawater (e.g. Veizer et al. 1999; McArthur et al, 2001), the ${ }^{87} \mathrm{Su} /{ }^{66} \mathrm{Sr}$ ratio of the seawater contemporaneous to Opalinus Clay sedimentation during the Middle Jurassic was at about 0.70730 (Fig. 13b), which is in the analytical uncertainty with that of an echinoderm value of 0.70733 , but significantly below that of bivalve shells at 0.70755 (de Haller

\begin{tabular}{|c|c|c|c|c|c|c|c|c|c|}
\hline Eirt & Perifod & Eprosh & silage & Age Ma) & Sea moverntanls & Totenic phtases & Teetonke negirine & Pore water dynamizs & 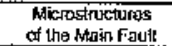 \\
\hline \multirow[t]{7}{*}{ Ceniazolo } & Outemary & $\begin{array}{l}\text { Hollopene } \\
\text { Pैhyistocine }\end{array}$ & 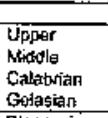 & $\begin{array}{l}0.02 \\
0.13 \\
0.78 \\
1.90 \\
2.58 \\
\end{array}$ & \multirow[b]{6}{*}{ 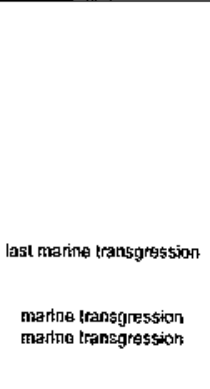 } & & \multirow{5}{*}{ conpresslon. } & \multirow{5}{*}{$\begin{array}{l}\text { expustiton } \\
\text { of porre wister }\end{array}$} & \\
\hline & Nenglene & Pillotenes & $\begin{array}{l}\text { Placenaian } \\
\text { Zanclear }\end{array}$ & $\begin{array}{l}3.60 \\
533 \\
\end{array}$ & & Jura thing:thlig and tolding & & & \multirow{2}{*}{ 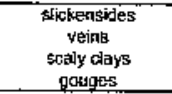 } \\
\hline & & \multirow[t]{2}{*}{ Whacerng } & 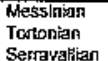 & $\begin{array}{l}7.25 \\
17.6 \\
11.8\end{array}$ & & $=$ etplith & & & \\
\hline & & & $\begin{array}{l}\text { Langhidan } \\
\text { Burdiganlan } \\
\text { Apullantan }\end{array}$ & $\begin{array}{l}16.0 \\
20.4 \\
23.0 \\
\end{array}$ & & no major deforration & & & \multirow{4}{*}{ 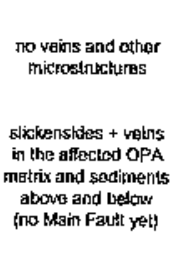 } \\
\hline & Pisegquene & Obinotsts & $\begin{array}{l}\text { Chähisan } \\
\text { Runeltarn. }\end{array}$ & $\begin{array}{l}28 . f \\
33.9\end{array}$ & & & & & \\
\hline & & Eocone & 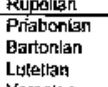 & $\begin{array}{l}33.9 \\
37.8 . \\
41.2 \\
47.8\end{array}$ & & 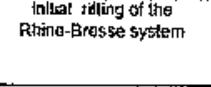 & exfansion & $\begin{array}{l}\text { probeble trinoduclior } \\
\text { of new pore water }\end{array}$ & \\
\hline & & Pritecene & 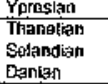 & $\begin{array}{l}56.0 \\
59.2 \\
61.6 \\
66.0\end{array}$ & $\begin{array}{l}\text { Hialus (eroded } \\
\text { of nivid depositedy }\end{array}$ & & & $\begin{array}{l}\text { probatste expulsien } \\
\text { of Inuald pore water }\end{array}$ & \\
\hline
\end{tabular}

Fig. 12 Sketch summarizing the sticcessive steps of the evolution of the Opalinus Clay (OPA) based on structural and petrographic obscrvationts and the herein oblained geochemical data. Furher references ase in the text 

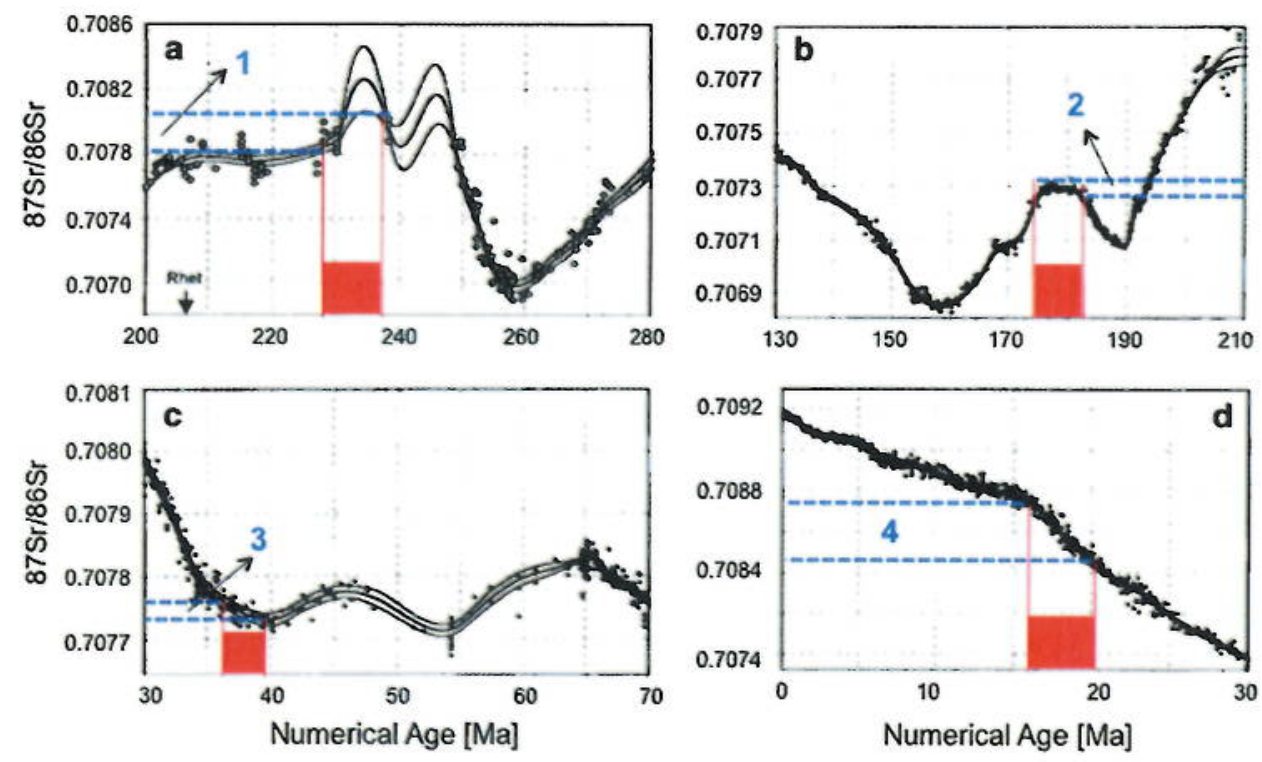

Fig. 13 Secular variation of the ${ }^{87} \mathrm{Sr} /{ }^{86} \mathrm{Sr}$ ratio from world seawater (adapted from McArthur et al. 2001): the sketch a outlines the period from 280 to $200 \mathrm{Ma}$ with the specific period highlighted by a red sector that corresponds to the hypothetic ${ }^{87} \mathrm{Sr} /{ }^{86} \mathrm{Sr}$ ratio framed as zone 1 on the ${ }^{87} \mathrm{Sr} /{ }^{86} \mathrm{Sr}$ ratio that de Haller et al. (2014) speculated as the Triassic fluid supply to the Opalinus Clay (OPA) (see text for further explanation). The sketch b presents the period between 210 and $130 \mathrm{Ma}$ including the deposition time of the Opalinus Clay

et al. 2014), as well as below those of the diffuse calcite of the matrix (de Haller et al. 2014; Techer et al. 2017). Fossils like those discussed here basically reflect seawater environments, as their ${ }^{87} \mathrm{Sr} /{ }^{86} \mathrm{Sr}$ ratios necessarily record the $\mathrm{Sr}$ signature of the seawater in which they were living. Therefore, the ${ }^{87} \mathrm{Sr} /{ }^{86} \mathrm{Sr}$ ratio of the calcite from one of them above that of the contemporaneous seawater indicates that it is no longer representative of the original marine environment, but necessarily of a further recrystallization episode (Faure 1986). The same most probably occurred for the initial sedimentary calcite of the Opalinus Clay that registered an increase of its ${ }^{87} \mathrm{Sr} /{ }^{86} \mathrm{Sr}$ ratio due to diagenetic recrystallization with interactions between pore-waters and fragile detrital minerals that potentially carry and exchange radiogenic ${ }^{87} \mathrm{Sr}$ with their environment (e.g. Clauer et al. 1975). Even if of limited intensity, such interactions may have induced release of small amounts of radiogenic ${ }^{87} \mathrm{Sr}$ by the altering minerals that increased the ${ }^{87} \mathrm{Sr} /{ }^{86} \mathrm{Sr}$ ratio of the diagenetically diffuse calcite from sediment matrix.

\subsection{Some pending aspects}

The heterogeneous ${ }^{87} \mathrm{Sr} /{ }^{86} \mathrm{Sr}$ ratio of the diffuse calcite of the undeformed Opalinus Clay matrix from outside and inside the Main Fault suggest limited exchanges in variably

highlighted by the red sector that corresponds to the ${ }^{87} \mathrm{Sr} /{ }^{86} \mathrm{Sr}$ ratio outlined by the zone 2 . The sketch $\mathbf{c}$ outlines the period from 70 to $30 \mathrm{Ma}$ corresponding to the potential Priabonian marine seawater invasion outlined by the red sector with the corresponding ${ }^{87} \mathrm{Sr} /{ }^{86} \mathrm{Sr}$ ratio of the marine water in the zone 3 . The sketch d outlines the most recent period between 30 and $0 \mathrm{Ma}$, giving the ${ }^{87} \mathrm{Sr} /{ }^{86} \mathrm{Sr}$ ratio of the Burdigalian seawater in the red sector with the corresponding ${ }^{87} \mathrm{Sr} /{ }^{86} \mathrm{Sr}$ ratio in the zone 4 . More information is in the text

small volumes during progressive burial, rather than flows of large volumes of fluids carrying isotopically homogeneous $\mathrm{Sr}$ and expected during sudden subsidence episodes by nearby tectonic activity. Other aspects need to be addressed further to possibly provide additional information useful for a concept of the regional evolution.

\subsubsection{The variable ${ }^{87} \mathrm{Sr} /{ }^{86} \mathrm{Sr}$ signature of the diffuse calcite from undeformed Opalinus Clay matrix}

Diagenetic interactions between seawater and fragile ${ }^{87} \mathrm{Sr}-$ bearing minerals do not explain why the $\mathrm{Sr}$ isotopic signature of the diffuse calcite from Opalinus Clay matrix is heterogeneous. Indeed, a regional evolution with limited uplift and subsidence episodes induces rather limited fluid migrations and mixings, therefore small but significant local variations of the ${ }^{87} \mathrm{Sr} /{ }^{86} \mathrm{Sr}$ ratio from diffuse calcite. It might also be that the final tectonic episode affecting the Opalinus Clay in the Main Fault was not penetrative enough to inject large amounts of fluids into the rock material beyond the microstructures, and therefore to erase potential records of successive fluid migrations. It can probably be assumed that most of the fluids with homogeneous ${ }^{87} \mathrm{Sr} /{ }^{86} \mathrm{Sr}$ ratios were generated during tectonic activity in the microstructures, mostly of the Main Fault. In fact, limited amounts of this "homogeneous" Sr from fluid 
flows that potentially affected the original ${ }^{87} \mathrm{Sr} /{ }^{86} \mathrm{Sr}$ ratios of the diffuse calcite from matrix, and consequently the connate waters, seem to have diffused into the Opalinus Clay matrix of the fault volume, recorded for instance by the ${ }^{87} \mathrm{Sr} /{ }^{86} \mathrm{Sr}$ ratio of the diffuse calcite in the scaly clays and the matrix around the veins, the case of the gouges remaining different (Fig. 9).

\subsubsection{Origin of the fluids that precipitated the infillings of the microstructures}

The ${ }^{87} \mathrm{Sr} /{ }^{86} \mathrm{Sr}$ ratio of the fluids that flew within the microstructures of the Main Fault is very homogeneous at a mean $0.70774 \pm 0.00001(2 \sigma)$ relative to a more widely scattered ${ }^{87} \mathrm{Sr} /{ }^{86} \mathrm{Sr}$ ratio of the diffuse calcite from undeformed Opalinus Clay of inside and outside the Main Fault (Fig. 9b). It is clear that the pore-waters of the Opalinus Clay and of the sediments below and above, as well as of the carbonate-rich sandy facies (CF1) close to the Main Fault could not contribute to the chemical composition of the fluids that migrated within the studied microstructures. The diffuse calcite of the sediments surrounding the Opalinus Clay is characterized by low ${ }^{87} \mathrm{Sr} /{ }^{86} \mathrm{Sr}$ ratios and high $\mathrm{Ca} / \mathrm{Sr}$ values, the latter ratio making possible a potential $\mathrm{Ca}$ contribution to the migrating fluid(s), but not explaining their high $\mathrm{Sr}$ isotopic composition. In this context, the hypothesis promoted by de Haller et al. (2014) about Triassic fluids having moved upward during the tectonic activity of the Main Fault along the described microstructures appears debatable because of the inappropriate ${ }^{87} \mathrm{Sr} /{ }^{86} \mathrm{Sr}$ ratios of the potential initial fluid contributor(s). As already mentioned, the ${ }^{87} \mathrm{Sr} /{ }^{86} \mathrm{Sr}$ ratios of the Triassic seawater are quite scattered, from 0.7078 to 0.7081 , above the reference value of 0.70774 (McArthur et al. 2001; Fig. 13a). Of course, it can be argued that a few values are below the $0.7078 \mathrm{limit}$ and/or that the values provided by Veizer et al. (1999) fit better than those by McArthur et al. (2001), which is not necessarily a solid argument in the context. Also, as already stated, the connate waters of the Opalinus Clay matrix that precipitated the diffuse calcite could not contribute to the fluids from microstructures for two determining reasons because of their far too widely scattered ${ }^{87} \mathrm{Sr} /{ }^{86} \mathrm{Sr}$ ratio. It is known for long (Boger and Faure 1974) that a Sr isotopic signature of a fluid or mineral cannot become homogeneous by any kind of mixing with an additional component. The second reason is physical: the results discussed above have shown that the flowing fluids diffused into the host rocks, especially around the veins, which renders improbable any supply of pore fluids to the flows.

Alternatively, the uniform ${ }^{87} \mathrm{Sr} /{ }^{86} \mathrm{Sr}$ ratio of the calcite infillings from most microstructures suggests a large and unique reservoir for the interacting fluids, in order to insure precisely that constant $\mathrm{Sr}$ isotope composition for the fluids that generated all visible infillings. In turn, such a large volume of fluids with a homogeneous ${ }^{87} \mathrm{Sr} /{ }^{86} \mathrm{Sr}$ ratio calls for seawater. However, the elemental composition of the fluids that generated the infilling precipitations was not quite homogeneous, which requires interactions with wall rocks of varied elemental compositions, but with identical ${ }^{87} \mathrm{Sr} /{ }^{86} \mathrm{Sr}$ ratios, pointing to minerals that are lacking radioactive ${ }^{87} \mathrm{Rb}$, in fact essentially carbonates, salts, oxides, ... (Faure 1986). If the fluids that interacted with the carbonate and sulfate infillings with analytically identical ${ }^{87} \mathrm{Sr} /{ }^{86} \mathrm{Sr}$ ratios originated from an important reservoir, likely of marine origin, the ${ }^{87} \mathrm{Sr} /{ }^{86} \mathrm{Sr}$ ratio of this seawater was necessarily of $0.70774 \pm 0.00001$, which is the mean ${ }^{87} \mathrm{Sr} /{ }^{86} \mathrm{Sr}$ ratio of the infillings from studied microstructures. This seawater ${ }^{87} \mathrm{Sr} /{ }^{86} \mathrm{Sr}$ signature identifies the Upper Eocene timing, between about 38 and $34 \mathrm{Ma}$ ago, on the $\mathrm{Sr}$ isotope chronostratigraphic scale with a few older ${ }^{87} \mathrm{Sr} /{ }^{86} \mathrm{Sr}$ ratios that are identical but scattered, while those of the younger seawaters increase straight (McArthur et al. 2001; Fig. 13c, d). Considering all approximations and uncertainties of such modeling, it is necessary to evaluate also the paleogeographic investigations to identify marine invasion(s) that could have potentially invaded the Mont Terri region during the period of concern here. A possible marine invasion coming from western Bresse Graben along the Rhine-Bresse transfer zone was postulated to have reached an area close to the study region during the Upper Eocene Priabonian from 38 to $34 \mathrm{Ma}$ ago (Sissingh 2006). A second marine incursion coming from southern Upper Rhine Graben during the Late Rupelian between 34 and $28 \mathrm{Ma}$ ago was also documented in many studies (Berger et al. 2005b; Hinsken et al. 2007; Pirkenseer 2007).

Sediments recording the Priabonian marine transgression into the Delémont Basin were not reported so far in the literature. Most of the scientific community stands with the sedimentological description of only one regional seawater invasion during the Rupelian into the Mont Terri region that was characterized by two short transgressions coming from southern Upper Rhine Graben (e.g. Braillard 2006; Roussé 2006; Picot et al. 2008). The first of these two pulses is documented by deposition of the "Conglomérats de Porrentruy" in the nearby Ajoie Basin with a short and discrete seawater record at $33 \mathrm{Ma}$. The second invasion occurred slightly later at 32-30 Ma ago, with deposition of the "Meeressand and Septarienton" sediments in the Delémont Basin (Fig. 14). The next regional marine transgression has been set during the Burdigalian (20-16 Ma ago) with deposition of the "Upper Marine Molasse" (UMM) from Swiss Molasse Basin to the south. This last invasion can be discarded in our fluid-flow model, on the basis of its just mentioned significantly higher seawater ${ }^{87} \mathrm{Sr} /{ }^{86} \mathrm{Sr}$ ratios ranging from 0.7084 to 0.7087 (Fig. 13d; McArthur et al. 


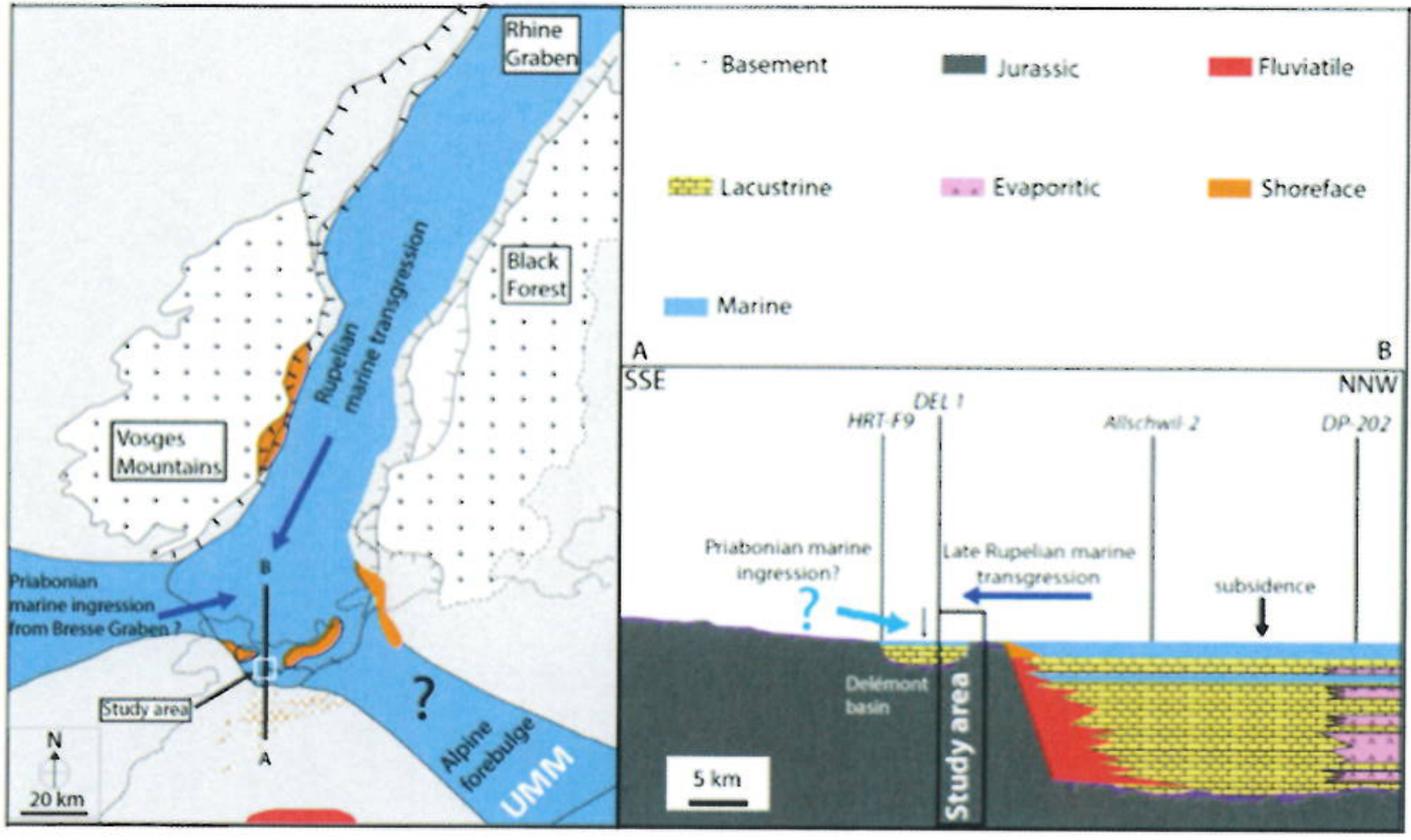

Fig. 14 A regional sketch of the paleo-structural situation of the Delémont Basin and its neighborhood during the Rupelian. On the left sketch are indicated the study area and the SSE-NNW cross-section

2001) that do not fit at all with those of the fluids responsible for the microstructural infillings. In summary, the Sr isotope chronostratigraphy points to a sea invasion into the Delémont Basin between 38 and $36 \mathrm{Ma}$, whereas the sedimentary records point to a younger episode from 32 to $30 \mathrm{Ma}$, with an additional discrete sea invasion slightly earlier at $33 \mathrm{Ma}$, all based on sediment records.

The purpose is not to start here a debate comparing the potentials of the two applied dating techniques. Both have solid but also weak aspects such as approximate age estimations for the $\mathrm{Sr}$ isotope chronostratigraphy, but with the certitude that the seawater $\mathrm{Sr}$ signature cannot record an invasion younger than $36 \mathrm{Ma}$ because of the significant increase of the marine ${ }^{87} \mathrm{Sr} /{ }^{86} \mathrm{Sr}$ ratio afterwards, as discussed above. Conversely, the sedimentary biostratigraphic approach provides generally precise ages for the deposited marine sediments on the basis of their varied microfauna (e.g. foraminifera), which is not the case here because the biozones are long ranging. It has also the weakness to be only based on accessible deposits; dating becomes problematic if the necessary records were either not deposited or eroded meanwhile, which cannot be ignored. In the present case, a temporary marine connection was stipulated between the Mulhouse Basin and the Molasse Basin during the Upper Eocene (Sittler 1965). Sissingh $(1998,2006)$ postulated a with the location of the drillings (vertical bars) on which the stratigraphic interpretation was based (modified from Pirkenseer 2007)

regional marine Priabonian transgression southwards from Upper Rhine Graben, obviously on the basis of foraminifera descriptions in drilling material described near the Fribourg/ Brisgau area by Ohmert (1993), but without records yet reported in the Delémont and Ajoie basins. As the potential Priabonian sea transgression occurred during a siderolithic episode on the continent, it could have interacted with the newly formed karstic system that was enhanced by contemporaneous extensional faulting of the Rhine-Bresse Graben transfer zone, rather than depositing sediments (Pirkenseer, pers. comm.). However, foraminifera have anyway to be described in the modified karst materials to support this hypothesis. At this point, the scenario still lacks occurrence of appropriate sediment relicts with determining microfossils.

As the contemporaneous rifting episode was mainly in an extension mode associated with a strike-slip component in the transfer zone linking the Bresse and Rhine grabens, no immediate expulsion of the seawater trapped in a reservoir to be identified occurred expectedly. However, it is needed to identify the potential reservoir that had to be outside the Opalinus Clay, as it did not favor significant interactions with either the early-crystallized calcite, or the detrital clay-type materials of the Opalinus Clay matrix. The constant ${ }^{87} \mathrm{Sr} /{ }^{86} \mathrm{Sr}$ ratio of the microstructural infillings 
calls for a carbonate reservoir, which could have resulted precisely from Priabonian regional siderolithic episode between 37 and $34 \mathrm{Ma}$ that facilitated formation of a karstic system (Braillard 2006) above the Opalinus Clay, when the thin-skinned deformation of the Jura front reached the Mont Terri region between approximately 10 and $3 \mathrm{Ma}$. Development of the Main Fault is associated with this deformation phase that expulsed the fluids into the microtectonic structures of the Main Fault, inducing also the formation of discretely associated veins and slickensides in the sediments above and below the Opalinus Clay.

\subsubsection{The water-Opalinus Clay matrix interactions in the scaly clays and around the veins}

Expulsion of Priabonian seawater was probably synchronous with the vein and slickenside formation in the Opalinus Clay matrix and in the surrounding sediments due to folding of the Main Fault. This expulsion induced interactions between the fluids that precipitated calcite in the microstructures, as well as closely around these microtectonic features. These interactions around the veins outline a diffusion process into the undeformed Opalinus Clay based on the $\mathrm{Ca} / \mathrm{Sr}$ ratio and REE distribution patterns (Figs. 10, 11). Consequently, the flowing fluids within the veins did not accommodate connate waters, as the pressure in the microstructures was such that they diffused into the host rocks and not the other way around.

The case of the scaly clays appears slightly more complex than that of the undeformed Opalinus Clay matrix around the veins, as they seem to result tectonically from shear bands deriving into meso- to micro-folds. Arch et al. (1988) demonstrated that high water contents lead to an increased complexity in the shear zone geometry of claytype sediments. Such an interpretation supports the occurrence of fluid flows rather than limited interactions among almost immobile pore-waters and altering minerals. Also to be remembered is the fact that somehow static interactions between such waters and fragile minerals do probably not provide systematic homogeneous $\mathrm{Sr}$ isotopic and $\mathrm{Sr} / \mathrm{Ca}$ ratios for the analyzed microstructural infillings. In fact, the ${ }^{87} \mathrm{Sr} /{ }^{86} \mathrm{Sr}$ ratio of the leached $\mathrm{Sr}$ from scaly clays is similar to those of the undeformed matrix close to the veins. However, the more scattered $\mathrm{Ca} / \mathrm{Sr}$ ratios and REE distribution patterns of the scaly clays suggest varied compositions for the vein and gouge calcite relative to the diffuse calcite of the reference undeformed Opalinus Clay. This suggests also that the chemical signature of the analyzed infillings of the scaly clays are either more representative of the fluid-flow signatures like in the vein or gouge calcite and/or of those from diffuse calcite of the undeformed Opalinus Clay, depending on how sampling was made.

\subsubsection{What type of water-rock interactions in the gouges?}

Frictional sliding and abrasion are common processes in gouges, the constituting minerals being often smaller than those of their wall rocks. Indeed, the abundant nano-sized particles in gouges may result from combined cataclasis and pressure solution-precipitation that can occur by recrystallization of kinked and folded detrital clay particles (Solum 2003; Laurich 2015). From geochemical data, the interaction with fluid flows favoring illite neoformation has been described in larger gouges (e.g. Vrolijk and van der Pluijm 1999; Sasseville et al. 2008; Warr et al. 2014). Being considered as the most "evolved" micro-structural feature of the Main Fault (Laurich 2015), the gouges contain infillings with ${ }^{87} \mathrm{Sr} /{ }^{86} \mathrm{Sr}$ and $\mathrm{Ca} / \mathrm{Sr}$ ratios, and REE distribution patterns suggesting the supply of an additional fluid necessarily external, relative to those that interacted with the calcite infillings of the veins and the slickensides. The strikingly high $\mathrm{K}$ and $\mathrm{Na}$ contents of the leachates from gouges point towards an increased alteration of some of the constitutive minerals of the gouge protolith (Fig. 8), especially if one considers that all other microstructures host infillings that apparently interacted with only one fluid flow. For instance, dissolution of salt grains observed by scanning electron microscope, which appear not to have been in contact with the fluids in most microstructures, could explain the increased $\mathrm{K}$ and $\mathrm{Na}$ contents together with unchanged ${ }^{87} \mathrm{Sr} /{ }^{86} \mathrm{Sr}$ ratios for the gouge leachates that remain identical to those of the veins and slickensides.

Clearly, the high $\mathrm{Si} / \mathrm{Al}$ ratios and the high $\mathrm{K}$ contents of the leachates from gouges could not result from a "simple" solution-pressure process, as they would have also altered $\mathrm{K}$-alumino-silicates, which seems not to have been the case. Alternatively, minerals such as quartz grains or illiterich clay crystals that were described by Laurich (2015) are basically enriched in $\mathrm{Si}, \mathrm{Al}$ and $\mathrm{K}$, and could have precipitated in the gouges. In the case of the REE distribution patterns, the unexpected positive Sm anomaly has not yet, to the best of our knowledge, been reported in minerals like those studied here (Fig. 10; Piper and Bau 2013), inciting us to consider that its origin could be due to the occurrence of organics in the solutes of a supplementary fluid of external origin. In fact, the Rietheim Member of the Staffelegg Formation considered as the detachment horizon of the Main Fault (Nussbaum et al. 2017) consists here of "bituminous schists" that could have released fluids enriched in organics maturated during the faulting. In addition to Sm supply to the diffuse leachates of the gouges, it is needed to point also to a higher $\mathrm{P}$ content for the same leachates (Techer et al. 2017), and the combination of these two geochemical changes clearly support a supply of organic-derived solutes that could definitely not originate within the gouge volumes. 
In the delail, the gouges consist of a fine, distinct, darkblack microstructure that is characterized by a very homogeneous oricntation of its clay particles. The gouge of the Muin Fault consists of internal micrometer-wide shear zones, wider (50 $\mu \mathrm{m})$ ) shear bands, brighter wall-rock clasts and grain clasts (Fig. 4; Laurich 2015). In fact, we aimed to sub-sample only the dark gouge from locations with littie or no wall-rock clasts (7b in Fig. 2b). However, the ${ }^{87} \mathrm{Sr} /{ }^{86} \mathrm{Sr}$ and elemental signatures of the gouge leachates could have resulted from local interactions duc to a variabje "accessibility" of the fluids to the intemal gouge features, as well as from variable interactions with local host minerals, relative to limited fluid/wall-mineral interactions it the microtectonic "drains" of the Main Fault. In sammary, the differest elemental compositions of the leachates from gouge samples could have resulted from interactions with limited volumes of fluids of varied origins at different timings relative to those recorded in the calcite and celestite of the veins. However, variations sbotld have been detected in this case in the ${ }^{87} \mathrm{Sr} /{ }^{86} \mathrm{Sr}$ tatios of the calcite, due mainly to variable extents of the interactions and consequent varied addition of radiogenic ${ }^{87} \mathrm{Sr}$ retcased from altered ninerals. These minerals conld have been more sensitive to increased themal conditions during folding, but they cannot amount for the volume necessary for atl observed gouge infillings, moreover with homogeneous ${ }^{87} \mathrm{Sr} /{ }^{86} \mathrm{Sr}$ ratios.

\subsubsection{What origin for the present-day free waters from Opalitus Clay?}

Technical reports of research programs on the Mont Teri rock laboratory outline ${ }^{87} \mathrm{Sr} /{ }^{86} \mathrm{Sr}$ ratios, and $\mathrm{Ca}$ and $\mathrm{Sr}$ contents of "free" fluids recovered directly in rock segments isolated by packers after dry drillings (e.g. Pearson et at. 2003 ), Identified as "drill-hole flujds". "pore-waters" or "interstitial waters", these fluids yield ${ }^{87} \mathrm{Sr} /{ }^{86} \mathrm{Sr}$ ratios that are surprisingly within the range of those of the infillings from studied microtectonic features (Tabie 1). This isotopic identity could, of course, be completely fortujtous, as these "free" waters appear not to have interacted with the calcite from undeformed Opalinus Clay matrix. If they would have, their ${ }^{87} \mathrm{Sr} /{ }^{86} \mathrm{Sr}$ ratio should be much more scattered, as are the same ratios of the diffuse matrix calcite. Alternatively, these present-day waters collected after drilings into the Opainus Clay cannot correspond to older so-called "connate waters" from which the diffuse matrix calcite precipitated. Their ${ }^{87} \mathrm{Sr} /{ }^{86} \mathrm{Sr}$ ratios being identical to those of the microstructural infillings, they cannot derive from, nor can account for any kind of mixing with the pore-waters that generated the scattered ${ }^{57} \mathrm{Sr} /{ }^{86} \mathrm{Sr}$ ratios of the diffuse calcite.

The Priabonian seawater stored in a karstic reservoir closety above the Opalinus Clay, or in the fault system resulting from Rhine Graben tifting, had visibly no detectable interaction with minerals characterized by ${ }^{87} \mathrm{Sr}-$ enriched soluble minerat phases before the beginning of the ftuid injections into the microstrzctures of the Main Fault, as weil as into microstructures outside the fault. Clearly, the identity among the ${ }^{87} \mathrm{Sr} /{ }^{86} \mathrm{Sr}$ ratios of the present-day pore-waters and those of the calcite from microtectonic features was unexpected; it is even intriguing. Despite the still limited number of available pore-water analyses, the systematic proximity of their ${ }^{87} \mathrm{St} /{ }^{86} \mathrm{Sr}$ ratios with those of the calcite from most microstructures of the Main Fault points towards the possibility that these free waters are still able to circulate along the Opalinus Clay micrometer-thin shear zones and potentially along veins and stickensides. Alternatively, they seem not to diffuse into the undeforned matrix. The proximity of the ${ }^{87} \mathrm{Sr} /{ }^{86} \mathrm{Sr}$ ratios of the microtectonic features and the present-day free waters that are sti]: "mobile" in the Opalinus Clay certainly needs

Table 1 The $\mathrm{Ca}$ and $\mathrm{Sr}$ concentrations, and the $1 / \mathrm{Sr}$, Ca/Sr and ${ }^{87} \mathrm{St} /{ }^{86} \mathrm{Sr}$ ratios of pore-waters from boreboles into the Opalinus Clay fram Mont

\begin{tabular}{|c|c|c|c|c|c|c|c|}
\hline Borethole & Sample ID & $\mathrm{SI}^{\prime}(\mathrm{Hg} / \mathrm{g})$ & $\mathrm{I} / \mathrm{Sr}$ & $\mathrm{Ca}(\mu \mathrm{g} / \mathrm{g})$ & $\mathrm{Ca} / \mathrm{Sr}$ & $87 \$ r / 86 \mathrm{Sr}( \pm 2 \sigma)$ & Origin dala \\
\hline & & & & & & $0.707705(2)$ & Tlis sudy \\
\hline BWS-A! & $A-1 / 4$ & 35.5 & 0.028 & 570 & 16.1 & $0.707651(22)$ & Pearson et al. (2003) \\
\hline \multirow[t]{2}{*}{ BWS-A2 } & $A-2 / 1$ & 21.5 & 0.047 & 43.2 & 201 & $0.707774(36)$ & Pearson et al. (2003) \\
\hline & $A-2 / 18$ & & & & 8.64 & $0.707750(?)$ & Pearson et al. (2003) \\
\hline BWS-A3 & $\Lambda-3 / 4$ & 31.6 & 0.032 & 283 & 8.96 & $0.707715(20)$ & Pearson et al. (2003) \\
\hline \multirow[t]{4}{*}{ BHT1 } & $\mathrm{HT} 2$ & 47.8 & 0.021 & 650 & 13.6 & $0.707677(12)$ & A. Vinsot (Andra) pers com \\
\hline & HT3 & 47.9 & .0 .021 & 650 & 13.6 & $0.707751(12)$ & A. Vinsol (Andra) pers con! \\
\hline & HT8 & 41.8 & 0.024 & 695 & 16.6 & $0.707651(13)$ & A. Vinsot (Andra) pers com \\
\hline & НТ10 & 42.8 & 0.023 & 695 & 16.2 & $0.707770(12)$ & A. Vinsol (Audra) pers com \\
\hline $\mathrm{BDS} 2$ & DS & 0.77 & 1.30 & 67.1 & 87.1 & $0.707730(10)$ & A. Vinsol (Andra) pers com \\
\hline BPCC2 & PPC & 26.6 & 0.038 & 62.2 & 2.34 & $0.707730(80)$ & A. Vinsot (Andra) pers con \\
\hline
\end{tabular}

? stands for Unkrown result 
more concerned interest about their origin(s). The most reasonable hypothesis to be formulated at this point is that the calcite infillings of the microstructures, rather than that of the undeformed matrix, seem to control the ${ }^{87} \mathrm{Sr} /{ }^{86} \mathrm{Sr}$ ratio of these present-day free waters that might interact with the identified infillings.

\subsection{The origin of the fluid flows and the timing of their circulation(s)}

On the basis of the homogeneous ${ }^{87} \mathrm{Sr} /{ }^{86} \mathrm{Sr}$ ratios of the vein calcite and celestite, the calcite associated with the slickensides of the Main Fault, the calcite from veins of the sediments above and below the Opalinus Clay, the Priabonian karstic reservoir or the contemporaneous regional fault system could have been progressively contracted, which initiated expulsion of the stored seawater into the microstructures of the progressively deformed matrix from Opalinus Clay, especially next to the Main Fault, and into those of the sediments around the Opalinus Clay. This seawater with stable ${ }^{87} \mathrm{Sr} /{ }^{86} \mathrm{Sr}$ ratios migrated along the microstructural drains that were built since the local rifting became active, especially along faults of the Rhine Graben rifting that reached the Jura region and more precisely the Mont Terri area during the Upper Eocene (Ustaszewsi et al. 2005; Ustaszewski and Schmid 2007; Nussbaum et al. 2011). Tectonic activity appears to have been the driving force for the faulting and associated migration of specific seawater along microtectonic features that developed during the folding process.

As the gouges contain here less calcite (Fig. 7a), probably dissolved by fluids of sulfate and/or phosphate type, the former on the basis of pyrite dissolution and celestite authigenesis in the gouges and the latter being plausible on the basis of higher P contents of the leachates from the gouges (Techer et al. 2017), these fluids were different from those of the vein and slickenside drains. Also they cannot result from sole pressure-solution process, as they do not explain the increased contents of $\mathrm{P}$ and the $\mathrm{Sm}$ positive anomaly. These combined increases can best be explained by the addition of organic solutes released by the Rietheim Formation during sliding of the fault. It looks like successive fluid pulses could have been driven during the late tectonic event corresponding to the formation of the Jura thrust-and-fault belt between 10.5 and $3 \mathrm{Ma}$. From $\mathrm{Sr}$ isotopic information, it can be postulated that this late episode did not activate some contemporaneous marine reservoir, because the ${ }^{87} \mathrm{Sr} /{ }^{86} \mathrm{Sr}$ ratio of the gouge calcite remained identical to that of the other leachates, suggesting a further contribution of the same initial reservoir, either karstic or fault-systemic. Furthermore, the present-day free fluids yield the same ${ }^{87} \mathrm{Sr} /{ }^{86} \mathrm{Sr}$ ratio, which confirms no supplementary fluid supply since faulting.

\subsection{What can still be improved?}

Timing of most major episodes that impacted the Opalinus Clay since deposition lacks precise numerical dating with constrained uncertainties on top of the detailed available sedimentological reconstructions. Also, more elemental and isotopic determinations on infillings of microstructures around the Main Fault would definitely help detailing more the impact(s) of the successive tectonic episodes affecting the Opalinus Clay. In fact, a more precise dating of the Main Fault folding is potentially feasible on the basis of an appropriate extraction of the authigenic illite crystals, which occurrence appears plausible in the gouge volumes on the basis of electron-microscope observations (Laurich 2015) and elemental chemistry of the leachates (Techer et al. 2017). Indeed, direct isotopic dating becomes likely if a clean separation of pure authigenic illite crystals is feasible, for instance, on the basis of presently available sophisticated methods of separating nanometer-sized illite crystals from detrital counterparts. Separation of such nanometer-sized illite crystals is now well mastered (Środoń et al. 1992), and many direct isotopic dating of such small-sized separates of bentonites (e.g. Clauer et al. 1997, 2013; Środoń et al. 2009) and sandstones (Clauer et al. 2004; Blaise et al. 2015) are now available by the K$\mathrm{Ar}$ and $\mathrm{Rb}-\mathrm{Sr}$ methods. Nanometric separation of illite crystals and their isotopic dating have first been applied to bentonite beds, because these units lack detrital components, which facilitated interpretation of the isotopic ages. Since, the method has been applied to sandstones with variable success clearly depending on how separation of the authigenic fraction can be technically completed. Here, the attempt is applied for the first time, to the best of our knowledge, on $<0.02 \mu \mathrm{m}$ separates of discrete gouge samples from shales. The preliminary data show that complete separation of pure authigenic illite crystals has yet not been successful. However, on the basis of a fairly constrained identical age for the detrital illite, and of wellconstrained $\mathrm{K}$ contents of the detrital (at about 3\%) and authigenic illite separates (at about $5 \%$ ), preliminary $\mathrm{K}-\mathrm{Ar}$ ages for the authigenic illite crystals from gouge samples range between 9 and $4 \mathrm{Ma}$ with uncertainties yet difficult to evaluate precisely, but which could be at a $\pm 10 \%$ level. This age range represents a reasonable first estimation of the tectonic event responsible for folding of the Main Fault, formation of the associated microtectonic structures and precipitation of most infillings, especially of illite in the gouges. Independently, the authigenic illite from deeply buried Opalinus Clay near Kreuzlingen in northeastern Switzerland could have crystallized slightly earlier between 11 and $9 \mathrm{Ma}$, because linked to the diagenetic burial episode and not to the tectonic folding identified in the Main Fault. 
A further pending question is about the origin of the present-day free waters, and about the extent of their interactions with the host rocks for which the envisioned interpretation has still to be tested, improved and consolidated, possibly on the basis of an enlarged analytical database.

\section{Conclusions}

Combined to a detailed observation atsd description of the microtectonic structures identified in the Main Fault that intersects the Opalinus Clay in the Mont Terri Rock Laboratory, this study focuses on an elemental and Sr isotopic investigation of associated micro-sanpled calcite and celestite. Calcite and celestite crystallized at the same time in the microstructures of the Main Fault from a fiuid either bi-carbonated or sulfated, but with analytically identical ${ }^{87} \mathrm{Sr} /{ }^{36} \mathrm{Sr}$ ratios. The undeformed Opalinus Clay matrix preserved as a relict within the Main Fault contains leachable ${ }^{87} \mathrm{Sr} /{ }^{86} \mathrm{Sr}$ ratios that are closer to those of the microtectonic infillings than to those of the undeformed Opalinus Clay outside the Main Fault, which ${ }^{87} \mathrm{Sr} /{ }^{86} \mathrm{Sr}$ ratios are unexpectedly varied. The $\mathrm{Sr}$ isotopic ratio of the diffuse calcite from unleforned matrix suggests that the fock volume within the fault has been slightly contaminated by the fuid flows that circulated in the microtectonic structures, diffusing discretely into the surrounding hos: rock. Therefore, the pore-waters that generated the caicite of the Opalinus Clay matrix could not contribute to the flowing fluids because: (1) flowing fluids diffused from veins at least into the host matrix, and (2) the widely varied ${ }^{87} \mathrm{Sr} /{ }^{86} \mathrm{Sr}$ ratios of the residual pore-waters cannot be accommodated into the nartow ${ }^{87} \mathrm{Sr} /{ }^{86} \mathrm{St}$ ratio of the flowing fluids.

The ${ }^{87} \mathrm{Sr} /{ }^{86} \mathrm{Sr}$ of the infillings from microtectonic structures of the Main Fautt range very nartowly at $0.70774 \pm 0.00001 \quad(2 \sigma)$, suggesting that the fluid flow(s) was (were) efficient enough to maintaits such a chemical homogencity in the different features, despite probable interactions with the wall rocks. The stane homogeneous ${ }^{87} \mathrm{Sr} /{ }^{86} \mathrm{Sr}$ ratio was also determined in the calcite veins of the Toarcian Staffelegg and Dogger Passwang Formations located respectively above and below the Opalinus Clay. The present interpretation calls for a temporaty storage of the fluids in a large homogeneous reservoir located slighty above the Opalinus Clay, like an "inftrite" marise reservoir, with a specific ${ }^{87} \mathrm{Sr}{ }^{86} \mathrm{Sr}$ ratio that points to Priabonian seawater supply (about 38-34 Ma ago) according to the $\mathrm{Sr}$ isotopic secular evolution of the serwater. This result is consistent with a possible sea incursion coming from western Bresse Graben through the Rhine-Bresse Graben transfer zone. However, this paleogeographic reconstruction is not yet unanimously accepted. as it cannot be ultimately verified due to the absence of known Priabonian sediments in the Mont Terri region. The causes for these lacking deposits can be multiple: either they were not found so far, were not deposited, or were eroded during a contemporaneous siderolithic episode. Thedefore, if assuming the Priabonian sea incursion, the
nfiltrated seawater could have been injected along veins and slickensides during the coeval rifing episode, resulting in the creation of the Rhine Graben and in associated extensional fatits affecting the entire Mesozoic sedimenary sequence as well as the basement.

The chemical composition of the calcite infillings from the gouges calls for the supply, on top of a pressure-soiution action, of an additional ftuid that wus different from those responsible for the crystallization of the vein and slickenside infillings, and also for that of the diffuse calcite of the Opalinus Clay matrix around the veins. The different chemical composition of the fiuids that precipitated the carbonates from the gouges is especially visible in the $\mathrm{Si}$ and Al correlation of the leachates titat suggests nanometer-sized illite-type crystallization. Calcite dissolution in the gouges seems to have been regulated by the dissolution of pyrite and concomitant precipitation of gypsum. Addition of this different flujd occurred most probably during the Majn Fault folding and sliding in the most deformed gouge microstructures. The resulting fluid probably interacted with minerals, which induced changes in their elemental compositions, but not their $\mathrm{Sr}$ isolopic ratios. Tectonic activity along with the regional stress was obviously the driving force for migration/injection of fluids in the microstructures probably initiated during the final EoOligocene rifting episode of the Upper Rhine Graben, before the ultimate thin-skinned deformation generated the Main Fault and the Mont Terri anticline about 9-4 Ma ago, as attested by preliminary $\mathrm{K}-\mathrm{Ar}$ ages.

Actowledgentents We are espceially thankful to Pierte De Canničre (FANC-AFCW) and Clatrdius Pirkenseer (Paleontologie A16 (F) of and University of Fribourg) for (heis extrencly derri Consortium and and improving reviews, to Paul Bossart (Mon FI Experiment, and to swisstopo) for support and funding of the ri Experind support for Andreas Gautschi (Nagra) for his conitituous intere do Agnès Viusot this research project. Special thanks are also due to Ages the datasel (Andra) who made available to us a pore-water of those she studies in the frame of the HT Experinem. Slomprove the thantiks are also due to

English prosentalion.

\section{References}

Agar, S. M., Prior, D. J., \& Bchrmaru, J. H. (\$989), Back-scaltered electon imagety of the tectonic fabrics of sonte fise-graines Implicalions for fabric nomenclature and deformation sediments: lmpications for fabies. Geolog, 17,

processes. Geology, Areb, J., Malman, A. 3., \& Kripe, R. 3. (1988). Shear-zone 
water content, strain rate and primary fabric. Journal of Structural Geology, 10, 91-99.

Berger, J. P., Reichenbacher, B., Becker, D., Grimm, M., Grimm, K., Picot, L., et al. (2005a). Paleogeography of the Upper Rhine Graben (URG) and the Swiss Molasse Basin (SMB) from Eocene to Pliocene. International Journal of Earth Sciences, 94, 697-710.

Berger, J. P., Reichenbacher, B., Becker, D., Grimm, M., Grimm, K., Picot, L., et al. (2005b). Eocene-Pliocene time scale and stratigraphy of the Upper Rhine Graben (URG) and the Swiss Molasse Basin (SMB). International Journal of Earth Sciences, 94, 711-731.

Blaise, T., Clauer, N., Cathelineau, M., Boiron, M. C., Techer, I., \& Boulvais, P. (2015). Reconstructing fluid-flow events in LowerTriassic sandstones of the eastern Paris Basin by elemental tracing and isotopic dating of nanometric illite crystals. Geochimica et Cosmochimica Acta, 176, 157-184.

Boger, P., \& Faure, G. (1974). Strontium-isotope stratigraphy of a Red Sea core. Geology, 2, 181-183

Bossart, P., Bernier, F., Birkholzer, J., Bruggeman, C., Connolli, P., Dewonck, S., Fukaya, M., Herfort, M., Jensen, M., Matray, J-M., Mayor, J. C., Moeri, A., Oyama, T., Schuster, K., Shigeta, N. Vietor, T., \& Wieczorek, K. (2017). Mont Terri rock laboratory, 20 years of research: introduction, site characteristics and overview of experiments. Swiss Journal of Geosciences, 110. doi:10.1007/s00015-016-0236-1 (this issue).

Bossart, P., \& Wermeille, S. (2003). Paleohydrological study of the surroundings of the Mont Terri Rock Laboratory. In P. Heitzmann, J.P. Tripet (Eds.), Mont Terri Project-Geology, Paleohydrology and Stress Field of the Mont Terri Region (pp. 45-64). Wabern, Switzerland: Reports of the Swiss Geological Survey Federal Office of Topography (swisstopo). http://www. mont-terri.ch.

Braillard, L. (2006). Morphogenèse des vallées sèches du Jura tabulaire d'Ajoie (Suisse): rôle de la fracturation et étude des remplissages quaternaires. Ph.D. dissertation, University of Fribourg, Switzerland.

Buatier, M. D., Chauvet, A., Kanitpanyacharoen, W., Wenk, H. R., Ritz, J. F., \& Jolivet, M. (2012). Origin and behavior of clay minerals in the Bogd fault gouge, Mongolia. Journal of Structural Geology, 34, 77-90.

Bundesamt für Energie (2008). Sachplan geologische Tiefenlager: Konzeptteil. Bern, Schweiz: Bundesamt für Energie BFE. http:/l www.bfe.admin.ch.

Burley, S. D., \& Worden, R. (2003). Sandstone diagenesis: Recent and ancient. Reprint series of the International Association of Sedimentologists (p. 656). New York: Wiley.

Cathelineau, M., Boiron, M. C., Fourcade, S., Ruffet, G., Clauer, N., Belcourt, O., et al. (2012). A major Late Jurassic fluid event at Belcourt, O., et al. (2012). A majo in western France: ${ }^{40} \mathrm{Ar} /{ }^{39} \mathrm{Ar}$ and $\mathrm{K}-\mathrm{Ar}$ dating, fluid chemistry, and related geodynamic context. Chemical Geology, 322, 99-120.

Clauer, N., Chaudhuri, S., Kralik, M., \& Bonnot-Courtois, C. (1993) Effects of experimental leaching on $\mathrm{Rb}-\mathrm{Sr}$ and $\mathrm{K}-\mathrm{Ar}$ isotopic systems and REE contents of diagenetic illite. Chemical Geology, 103, 1-16.

Clauer, N., Fallick, A. E., Eberl, D. D., Honty, M., Huff, W., \& Aubert, A. (2013). K-Ar dating and $\delta^{18} \mathrm{O}-\delta \mathrm{D}$ characterization of nanometric illite from Ordovician K-bentonites of the Appalachians: Illitization and the Acadian-Alleghenian tectonic activity. American Mineralogist, 98, 2144-2154.

Clauer, N., Hoffert, M., Grimaud, D., \& Millot, G. (1975). Composition isotopique du strontium d'eaux interstitielles extraites de sédiments récents: un argument en faveur de l'homogénéisation isotopique des minéraux argileux. Geochimica et Cosmochimica Acta, 39, 1579-1582.
Clauer, N., Rousset, D., \& Środoń, J. (2004). Modeled shale and sandstone burial diagenesis based on the $\mathrm{K}-\mathrm{Ar}$ systematics of illite-type fundamental particles. Clays and Clay Minerals, 52, 576-588.

Clauer, N., Środoń, J., Francú, J., \& Šucha, V. (1997). K-Ar dating of illite fundamental particles separated from illite/smectite. Clay Minerals, 32, 181-196.

de Haller, A., Mazurek, M., Spangenberg, J., \& Möri, A. (2014). Selfsealing of faults (SF) project: Final report. Mont Terri Technical Report, TR 08-02. Wabern, Switzerland: Federal Office of Topography (swisstopo). http://www.mont-terri.ch.

Degueldre, C., Scholtis, A., Thomas, B. (1998). WS-A experiment: Opalinus Clay groundwaters and colloids. A sampling and analysis exercise at Mont Terri (June/July 1997). Analytical results. Mont Terri Technical Note, TN 1997-20. Wabern, Switzerland: Federal Office of Topography (swisstopo). http:// www.mont-terri.ch.

Dehandschutter, B., Vandycke, S., Sintubin, M., Vandenberghe, N., \& Wouters, L. (2005). Brittle fractures and ductile shear bands in argillaceous sediments: Inferences from Oligocene Boom Clay (Belgium). Journal of Structural Geology, 27, 1095-1112.

Eiichi, I. (2012). Microstructure and origin of faults in siliceous mudstone at the Horonobe Underground Research Laboratory site, Japan. Journal of Structural Geology, 34, 20-29.

Faure, G. (1986). Principles of isotope geology (2nd ed., p. 608). New York: Wiley.

Haines, S. H., Kaproth, B., Marone, C., Saffer, D., \& van der Pluijm, B. (2013). Shear zones in clay-rich fault gouge: A laboratory study of fabric development and evolution. Journal of Structural Geology, 51, 206-225.

Hinsken, S., Ustaszewski, K., \& Wetzel, A. (2007). Graben with controlling syn-rift sedimentation: The Paleogene southern Rhine Graben as an example. International Journal of Earth Sciences, 96, 979-1002.

Hoth, P., Wirth, H., Reinhold, K., Bräuer, V., Krull, P., Feldrappe H. (2007). Einlagerung radioaktiver Abfalle in tiefen geologischen Formationen Deutschlands-Untersuchung und Bewertung von Tongesteinsformationen. Hannover, Germany: Bundesanstalt für Geowissenschaften und Rohstoffe (BGR).

Houben, M. E., Desbois, G., \& Urai, J. L. (2013). Pore morphology and distribution in the Shaly facies of Opalinus Clay (Mont Terri, Switzerland): Insights from representative 2D BIB-SEM investigations on $\mathrm{mm}$ to $\mathrm{nm}$ scale. Applied Clay Science, 71, 82-97.

Houben, M. E., Desbois, G., \& Urai, J. L. (2014). A comparative study of representative 2D microstructures in shaly and sandy facies of Opalinus Clay (Mont Terri, Switzerland) inferred from BIB-SEM and MIP methods. Marine and Petroleum Geology, 49, 143-161.

Jaeggi, D., Laurich, B., Nussbaum, C., Schuster, K., Connolly, P. (2017). Tectonic structure of the "Main Fault" in the Opalinus Clay, Mont Terri rock laboratory (Switzerland). Swiss Journal of Geosciences, 110. doi:10.1007/s00015-016-0243-2 (this issue).

Labaume, P., Maltman, A.J., Bolton, A., Tessier, D., Ogawa, Y., Takizawa, S. (1997). Scaly fabrics in sheared clays from the décollement zone of the Barbados accretionary prism. In Proceedings of the ocean drilling program. Scientific results (pp. 59-77). Ocean Drilling Program.

Lancelot, J. (Ed.). (2001). WS-G experiment: Geochemical pore water characterisation of reference argillaceous samples from the Mont Terri Rock Laboratory. Mont Terri Technical Note, TN 1999-43. Wabern, Switzerland: Federal Office of Topography (swisstopo). http://www.mont-terri.ch.

Laurich, B. (2015). Evolution of microstructure and porosity in faulted Opalinus Clay. Ph.D. dissertation, Rheinisch-Westfälische Techniche Hochschule (RWTH), Aachen, Germany. 
Laurich, B., Urai, J. L., Desbois, G., Vollmer, C., \& Nussbaum, C. (2014). Microstructural evolution of an incipient fault zone in Opalinus Clay: Insights from an optical and electron microscopic study of ion-beam polished samples from the Main Fault in the Mont Terri Underground Research Laboratory. Journal of Structural Geology, 67, 107-128.

Laurich, B., Urai, J. L., \& Nussbaum, C. (2016). Microstructures and deformation mechanisms in Opalinus Clay: Insights from scaly clay from the Main Fault in the Mont Terri Rock Laboratory (CH). Journal of Geophysical Research: Solid Earth. doi:10. 5194/se-2016-94. (submitted).

Lerouge, C., Gaucher, E. C., Tournassat, C., Négrel, P., Crouzet, C., Guerrot, C., et al. (2010). Strontium distribution and origins in a natural clayey formation (Callovian-Oxfordian, Paris Basin, France): A new sequential extraction procedure. Geochimica et Cosmochimica Acta, 74, 2926-2942.

Logan, J. M., Dengo, C. A., Higgs, N. G., \& Wang, Z. Z. (1992). Fabrics of experimental fault zones: Their development and relationship to mechanical behavior. International Geophysics Series, 51, 33-67.

Mazurek, M., Hurford, A. J., \& Leu, W. (2006). Unravelling the multi-stage burial history of the Swiss Molasse Basin: Integration of apatite fission track, vitrinite reflectance and biomarker isomerisation analysis. Basin Research, 18, 27-50.

McArthur, J. M., Howarth, R. J., \& Bailey, T. R. (2001). Strontium isotope stratigraphy: LOWESS Version 3: Best fit to the marine Sr-isotope curve 0-509 Ma and accompanying look-up table for deriving numerical age. The Journal of Geology, 109, 155-170.

Milliken, K. L., \& Reed, R. M. (2010). Multiple causes of diagenetic fabric anisotropy in weakly consolidated mud, Nankai accretionary prism, IODP Expedition 316. Journal of Structural Geology, 32, 1887-1898.

Mitra, G., \& Ismat, Z. (2001). Microfracturing associated with reactivated fault zones and shear zones: What it can tell us about deformation history. Geological Society of London, Special Publications, 186, 113-140.

Nagra (2008). Vorschlag geologischer Standortgebiete für das SMAund das HAA-Lager. Nagra Technischer Bericht, 08-04. Nagra, Wettingen, Switzerland. http://www.nagra.ch.

Nussbaum, C., Amann, F., Aubourg, C., \& Bossart, P. (2011). Analysis of tectonic structures and excavation induced fractures in the Opalinus Clay, Mont Terri underground rock laboratory (Switzerland). Swiss Journal of Geosciences, 104, 187-210.

Nussbaum, C., \& Bossart, P. (2008). Geology. In M. Thury, \& P. Bossart, (Eds.), Mont Terri rock laboratory project, programme 1996 to 2007 and results (pp. 29-37). Wabern, Switzerland: Federal Office of Topography (swisstopo). http://www.mont-terri.ch.

Nussbaum, C., Kloppenburg, A., Caër, T., Bossart, P. (2017). Tectonic evolution around the Mont Terri rock laboratory, northwestern Swiss Jura: constraints from kinematic forward modelling. Swiss Journal of Geosciences, 110 (this issue).

Nussbaum, C., Meier, O., Masset, O., Badertscher, N. (2006). Selfsealing of fault (SF) experiment drilling of resin impregnated boreholes part of drilling campaign of phase 11 drilling data, drillcore mapping and photo documentation. Mont Terri technical note, TN 2006-22. Wabern, Switzerland: Federal Office of Topography (swisstopo). http://www.mont-terri.ch.

Ohmert, W. (1993). Eine obereozäne Foraminiferenfauna aus dem südlichen Oberrhein-Graben. Zitteliana, 20, 323-329.

Pearson, F. J., Acros, D., Bath, D., Boisson, J. Y., Fernández, A. M., Gäbler, H.-E., et al. (2003). Mont Terri project: geochemistry of water in the opalinus clay formation at the Mont Terri rock laboratory. Federal Office for Water and Geology (FOWG), Geology Series No. 5. http://www.mont-terri.ch.

Pearson, F. J., Arcos, D., Jordi, B., Fernandez, A. M., Gaucher, E., Pena, J., et al. (2001). Geochemical modelling and synthesis
(GM) task: Compilation of aqueous geochemistry data collected during phases 4 and 5, rock property data from all phases and results of phase 5 geochemical modelling. Mont Terri technical note, TN 2000-36. Wabern, Switzerland: Federal Office of Topography (swisstopo). http://www.mont-terri.ch.

Picot, L., Becker, D., Cavin, L., Pirkenseer, C., LaPaire, F., Rauber, G., et al. (2008). Sédimentologie et paléontologie des paléoenvironnements côtiers rupéliens de la Molasse marine rhénane dans le Jura suisse. Swiss Journal of Geosciences, 101, 483-513.

Pin, C., Joannon, S., Bosq, C., Le Fèvre, B., \& Gauthier, P. J. (2003). Precise determination of $\mathrm{Rb}, \mathrm{Sr}, \mathrm{Ba}$ and $\mathrm{Pb}$ in geological materials by isotope dilution and ICP-quadrupole mass spectrometry following selective separation of the analytes. Journal of Analytical Spectrometry, 18, 135-141.

Piper, D. Z., \& Bau, M. (2013). Normalized rare earth elements in water, sediments, and wine: Identifying sources and environmental redox conditions. American Journal of Analytical Chemistry, 4, 69-83.

Pirkenseer, C. (2007). Foraminifera, ostracoda and other microfossils of the southern Upper Rhine Graben: palaeoecology, biostratigraphy, palaeogeography and geodynamic implications. Ph.D. dissertation, University of Fribourg, Switzerland.

Rieder, M., Cavazzini, G., D'Yakonov, Y. S., Frank-Kamenetskii, V. A., Gottardi, G., Guggenheim, S., et al. (1998). Nomenclature of the micas. Clays and Clay Minerals, 46, 586-595.

Roussé, S. (2006). Architecture et dynamique des séries marines et continentales de l'Oligocène moyen et supérieur du Sud du Fossé Rhénan: évolution des milieux de dépôts en contexte de rift en marge de l'avant-pays alpin. Ph.D. dissertation, University Louis Pasteur, Strasbourg, France.

Rutter, E. H., Maddock, R. H., Hall, S. H., \& White, S. H. (1986). Comparative microstructures of natural and experimentally produced clay-bearing fault gouges. Pure and Applied Geophysics, 124, 3-30.

Samuel, J., Rouault, R., \& Besnus, Y. (1985). Analyse multiélémentaire standardisée des matériaux géologiques en spectrométrie d'émission par plasma à couplage inductif. Analusis, 13, 312-317.

Sasseville, C., Tremblay, A., Clauer, N., \& Liewig, N. (2008). K-Ar time constraints on the evolution of polydeformed fold-thrust belts: the case of the Northern Appalachians (southern Québec). Journal of Geodynamics, 45, 99-119.

Schleicher, A. M., van der Pluijm, B. A., Solum, J. G., \& Warr, L. N. (2006). Origin and significance of clay-coated fractures in mudrock fragments of the SAFOD borehole (Parkfield, California). Geophysical Research Letters, 33, 1-5.

Sissingh, W. (1998). Comparative Tertiary stratigraphy of the Rhine graben, Bresse graben and Molasse basin: correlation of Alpine foreland events. Tectonophysics, 300, 249-284.

Sissingh, W. (2006). Syn-kinematic palaeogeographic evolution of the West European platform: Correlation with Alpine plate collision and foreland deformation. Geologie en Mijnbouw, 85, 131-180.

Sittler, C. (1965). Le Paléogène des fossés rhénan et rhodanien. Etudes sédimentologiques et paléo-climatiques. Strasbourg: Université de Strasbourg, Centre National de la Recherche Scientifique, Institut de Géologie.

Solum, J. G. (2003). Influence of phyllosilicate mineral assemblages, fabrics, and fluids on the behavior of the Punchbowl fault, southern California. Journal of Geophysical Research, 108, 1-12.

Środoń, J., Clauer, N., Huff, W., Dudek, T., \& Banas, M. (2009). $\mathrm{K}-\mathrm{Ar}$ dating of Ordovician bentonites from the Baltic Basin and the Baltic Shield: implications for the role of temperature and time in the illitization of smectite. Clay Minerals, 44, 361-387.

Środon, J., Elsass, F., McHardy, W. J., \& Morgan, D. J. (1992). Chemistry of illite/smectite inferred from TEM measurements of fundamental particles. Clay Minerals, 27, 137-158. 
Taylor, S. R. \& McLennan, S. M. (1985). The conthental crest: Its conponition and evolwion. Oxford: Blackweil.

Techer, 1., Clauer, N., Laurich, B., Nussbarum, C., Urai, J. L. (2017). Origin and titning of liuid hows in discrete petrofabric features of the "Main Frult" in the Opalinus Clay (Mont Terni. Switzerland): Clues from clemental and Sr isotopic analyses. Soumal of Sincticral Geology (subnitted).

Ujiie, K. Tanaka, H., Sutio, T., Tsalsumi, A., Mori, J. J., Kameda, J. ef af. (2013). Low cn-seismic shear stress on the Tohoku-Oki megathrust determined from labonatory experimests. Sctence, $342,121]-1214$.

Utai, J.r \& Wong, $S$. W. (1994). Deformation mechanisms in experimentally deformed shales. Annales Geophyricae, 12 , C98.

Ustaszewsi, K., Schuhmacher, M. E., \& Schmid, S. (2005). Simulfancous nornal faulting and extensional flexuring during rifing: An exanpte from the soullentmost Upper Rhine Graben. Antemational Journal of Earth Sciences, 94, 680-696.

Ustaszewski, K., \& Schmid, S. (2007). Latest Pliocene to recent lhick-skinned icelonics al the Upper Rhine. Graben-3tura Mountains junclion, Swiss Journal of Geosciences, 700, 293-312.
Vannucchi, P., Mattman, A., Bettelli, G., \& Clensell, B. (2003). Ol the nature of scaly fabric and scaly clay. Joumat of Structural Geology, 25, 673-688.

Veizer, I., Ala, D., Azmy, K., Bruckscben, P., Bubl, D., Brubn, F, et al. (I999). ${ }^{87} \mathrm{St}^{86} \mathrm{Sr}^{8} 8^{13} \mathrm{C}$ and $\delta^{18} \mathrm{O}$ evolution of Phanerozoic: scawater. Chemical Geology, 161, 59-88.

Vroijk, P., \& van der Pluijm, B. A. (1999). Clay gouge. Joumal of Structural Geology, 2I, 1039-1048.

Watr, L. N., \& Cox, S. (2001). Clay mineral transformations and weakening mechanisms along the Alpine Fault, New Zealand. Geological Society, Lotwon, Special Publications, I86, 85-101.

Warr, L. N., Wojalsehke, J., Carpenter, B. M. Marone, C, Schiteicher, A. M., \& van der Ptuijn, B. A. (2014). A "sliceand-vicw" (FIB-SEM) study of clay golge from the SAFOD crepping section of the 3 at $A$ adecas Fauli at about $2.7 \mathrm{~km}$ deptb. Journal of Structural Geology, 69, 234-244.

Worden, R. H. \& Morad, S. (2003). Clay minerals in sandstones: Controls on formation, distribution and evolution. Is R.H. Warden, S. Morad (Eds.), Clav mineral centents in sandstones. (pp.3-41). International Association of Sedimentologists Special Publication no. 34, Blackwell, Oxford. 